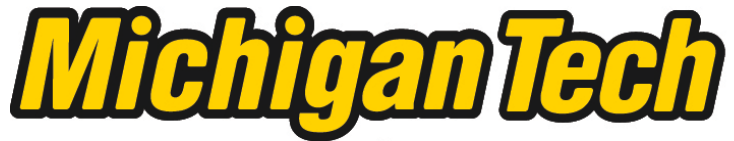 \\ Michigan Technological University Create the Future Digital Commons @ Michigan Tech
}

Performance characteristics and design recommendations for biomass-burning stoves using earthen construction materials

Nicholas H. Schreiner

Michigan Technological University

Follow this and additional works at: https://digitalcommons.mtu.edu/etds

Part of the Civil and Environmental Engineering Commons

Copyright 2011 Nicholas H. Schreiner

\section{Recommended Citation}

Schreiner, Nicholas H., "Performance characteristics and design recommendations for biomass-burning stoves using earthen construction materials ", Master's report, Michigan Technological University, 2011. https://doi.org/10.37099/mtu.dc.etds/513

Follow this and additional works at: https://digitalcommons.mtu.edu/etds

3 Part of the Civil and Environmental Engineering Commons 


\title{
PERFORMANCE CHARACTERISTICS AND DESIGN RECOMMENDATIONS FOR BIOMASS-BURNING STOVES USING EARTHEN CONSTRUCTION MATERIALS
}

By

Nicholas H. Schreiner

\begin{abstract}
A REPORT
Submitted in partial fulfillment of the requirements for the degree of MASTER OF SCIENCE

Environmental Engineering
\end{abstract}

MICHIGAN TECHNOLOGICAL UNIVERSITY

2011

(C) 2011 Nicholas H. Schreiner 
This report, "Performance Characteristics and Design Recommendations for Biomass-Burning Stoves Using Earthen Construction Materials," is hereby approved in partial fulfillment of the requirements for the degree of Master of Science in Environmental Engineering.

DEPARTMENT:

Civil and Environmental Engineering

Signatures:

Report Advisor:

Dr. Kurtis Paterson

Department Chair:

Dr. William Bulleit

Date: 


\section{TABLE OF CONTENTS}

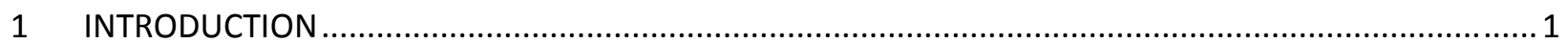

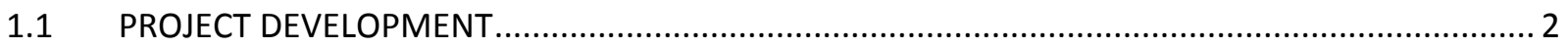

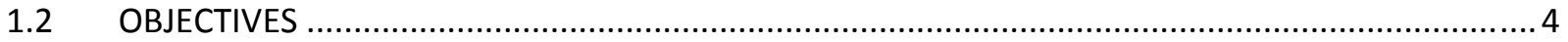

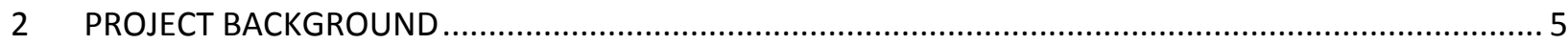

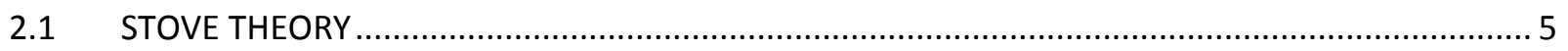

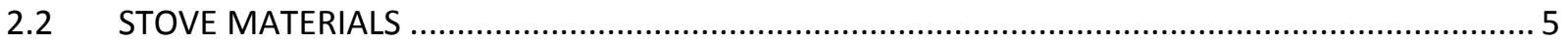

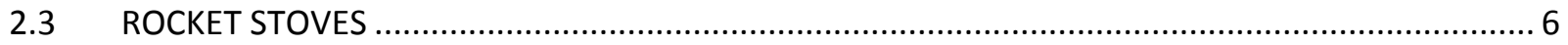

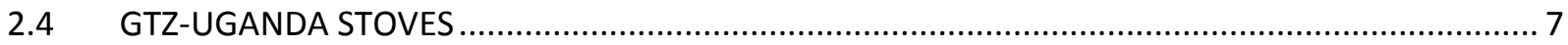

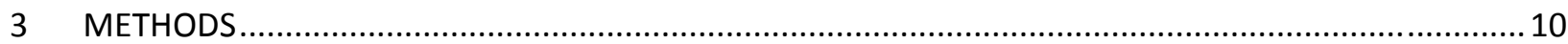

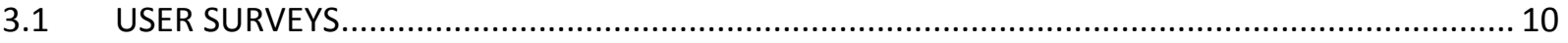

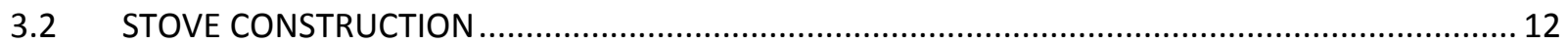

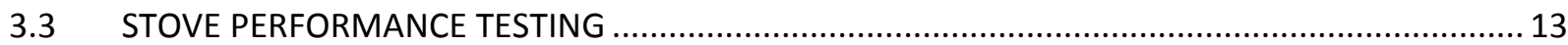

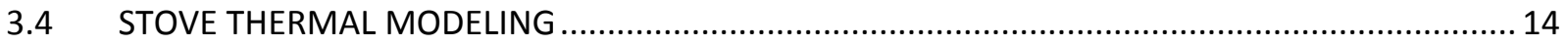

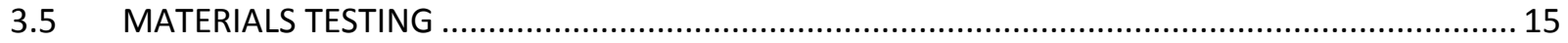

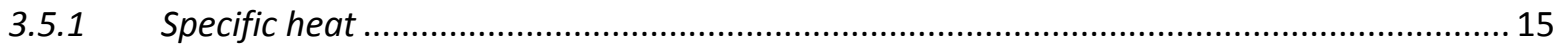

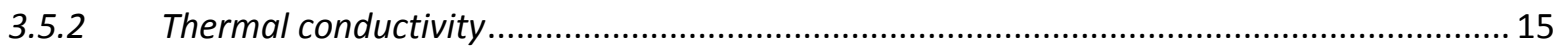

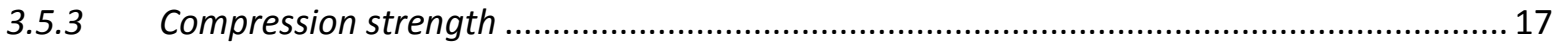

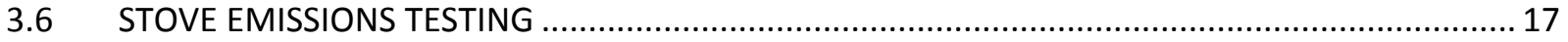

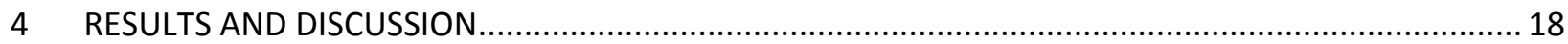

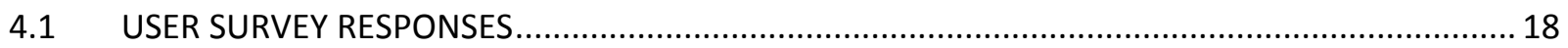

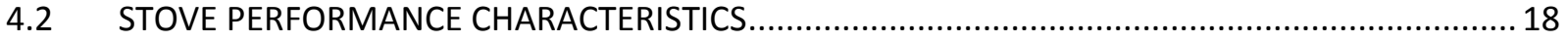

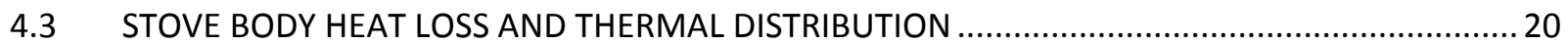

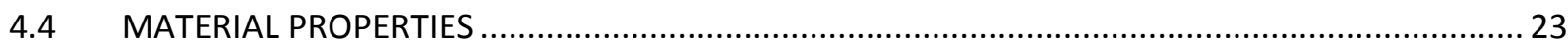

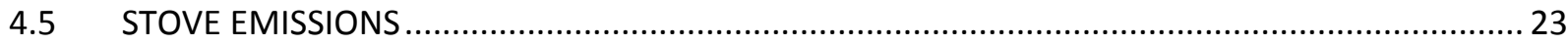

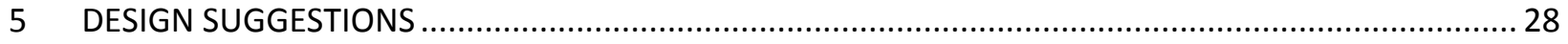

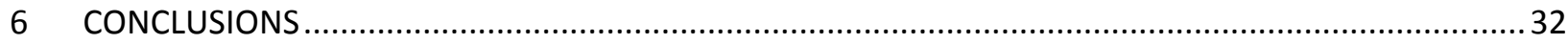

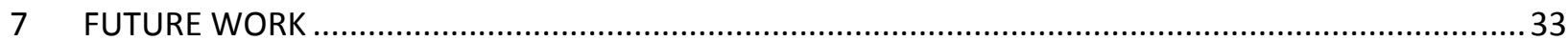

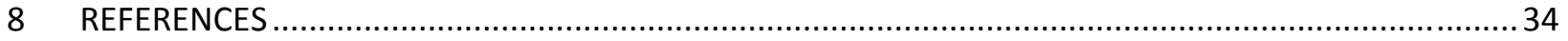

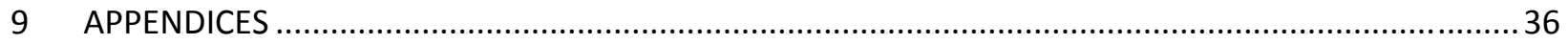

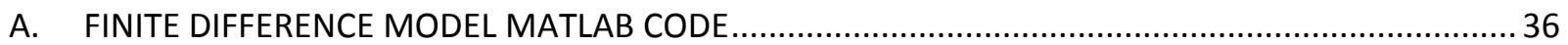




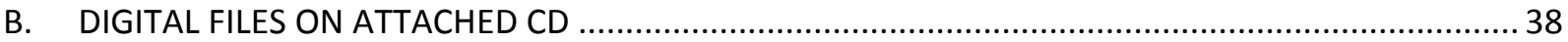

C. HUMAN SUBJECTS RESEARCH APPROVAL: MICHIGAN TECHNOLOGICAL UNIVERSITY .................. 39 


\section{LIST OF FIGURES}

Figure 1-1 Intervention opportunities 1

Figure 1-2 Project Site: Mauritania and Mali, Sahel Region of West Africa (Source: adapted from

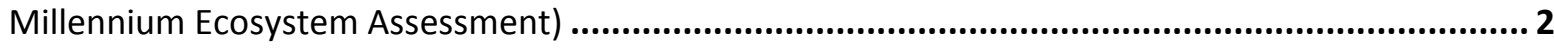

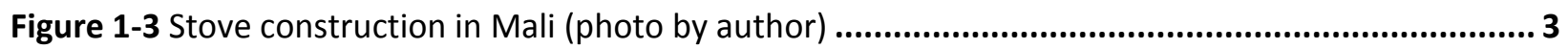

Figure 2-1 Rocket Stove (source: Aprovecho Institute) ................................................................. 7

Figure 2-2 Shielded Fire Stove (source: adapted from Ministry of Energy and Mineral Development,

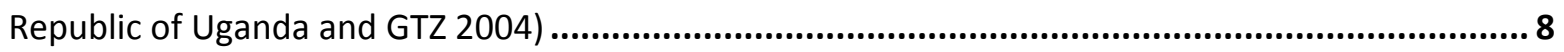

Figure 2-3 Rocket Lorena Stove (source: adapted from Ministry of Energy and Mineral Development,

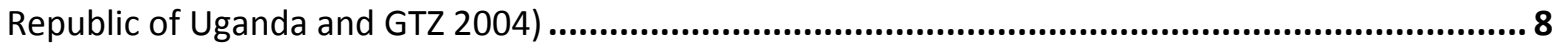

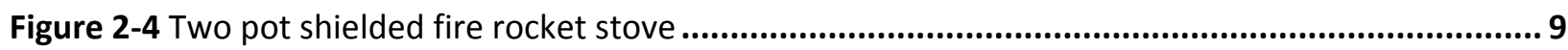

Figure 3-1 Schematic of shielded fire rocket stove constructed for laboratory performance and emissions testing (All dimensions in centimeters) ......................................................................................... 12

Figure 3-2 Shielded fire stove during a Water Boiling Test for $1 \mathrm{~L}$ of water in a $30 \mathrm{~cm}$ diameter pot ...... 13

Figure 3-3 Thermocouple placement and computational element nodes in the stove body .................. 14

Figure 3-4 Conductive heat transfer through a series of planar objects of varying thermal conductivity 16

Figure 3-5 Emissions sampling set up during stove testing; instrument sampling inlets were positioned 1

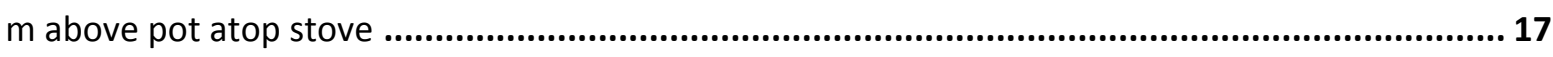

Figure 4-1 Stove body temperature distribution (Water Boiling Test: Run 1) ...................................... 21

Figure 4-2 Stove body temperature distribution (Water Boiling Test: Run 2) ..................................... 22

Figure 4-3 Averages of $\mathrm{CO}_{2}$ concentration of shielded fire stove emissions over three complete runs of the Water Boiling Test (WBT). Errors bars represent one standard deviation above and below mean values.

Figure 4-4 Averages of CO concentration of shielded fire stove emissions over three complete runs of the Water Boiling Test (WBT). Errors bars represent one standard deviation above and below mean values.

Figure 4-5 Averages of PM 2.5 concentration of shielded fire stove emissions over three complete runs of the Water Boiling Test (WBT). Errors bars represent one standard deviation above and below mean values

Figure 4-6 Moving average of PM 2.5 concentration of three stone fire emissions during one cold start test. Errors bars represent one standard deviation above and below mean values.

Figure 4-7 Moving average of PM 2.5 concentration of three stone fire emissions during one cold start test. Errors bars represent one standard deviation above and below mean values.

Figure 5-1 Stove inlet and combustion chamber dimensions (source: adapted from Aprovecho Institute) 
Figure 5-2 Pot skirt thickness and stove body diameter ............................................................... 30

Figure 5-3 Recho Roket Stove (source: http://www.rechoroket.com/) ............................................. 31 


\section{LIST OF TABLES}

Table 1-1 WHO Health Statistics for Mauritania and Mali (2008) (WHO Global Health Observatory

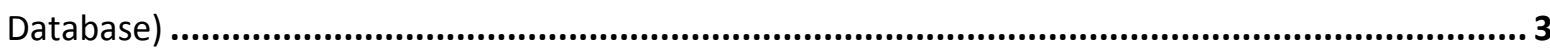

Table 3-1 Cooking practices and improved stove survey................................................................ 11

Table 4-1 Shielded fire water boiling test results. The Water Boiling Test was conducted in three phases, high power cold start, high power hot start, and simmer to evaluate the stove under varying operating conditions. The duration of the first two phases was dependent on the time needed to bring 2.5 liters of water to boil. The third, low power phase was 45 minutes in duration. During this time water was kept just below boiling to simulate slow cooking operations. Values shown as temperature corrected are adjusted to a standard $75^{\circ} \mathrm{C}$ temperature change ( $25^{\circ}$ to 100 ).

Table 4-2 Comparison of shielded fire stove and three stove fire performance results......................... 20

Table 4-3 Heat loss to stove body relative to total energy input ......................................................22

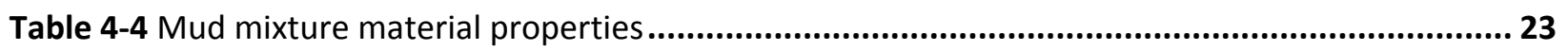

Table 4-5 Thermal properties of common combustion chamber materials (Andreatta 2003) ................ 23

Table 5-1 Inlet and combustion chamber dimensions based on cook pot diameter. $D$ is the inlet diameter, $\mathrm{H}$ is the height of the combustion chamber, $\mathrm{K}$ is the distance from the top of the fuel inlet to the outlet of the combustion chamber, and $L$ is the pot skirt gap (modified from Ministry of Energy and Mineral Development, Republic of Uganda and GTZ 2004)..................................... 29

Table 5-2 Summary comparison of cook stove design improvements .............................................. 31 


\begin{abstract}
This report provides an analysis of the thermal performance and emissions characteristics of improved biomass stoves constructed using earthen materials. Commonly referred to as mud stoves, this type of improved stove incorporates high clay content soil with an organic binder in the construction of its combustion chamber and body. When large quantities of the mud material are used to construct the stove body, the stove does not offer significant improvements in fuel economy or air quality relative to traditional open fire cooking. This is partly because a significant amount of heat is absorbed by the mass of the stove reducing combustion efficiency and heat transfer to the cook pot.

An analysis of the thermal and mechanical properties of stove materials was also performed. A material mixture containing a one-to-one ratio by volume of high content clay soil and straw was found to have thermal properties comparable to fired ceramics used in more advanced improved stove designs.

Feedback from mud stove users in Mauritania and Mali, West Africa was also collected during implementation. Suggestions for stove design improvements were developed based on this information and the data collected in the performance, emissions, and material properties analysis. Design suggestions include reducing stove height to accommodate user cooking preferences and limiting overall stove mass to reduce heat loss to the stove body.
\end{abstract}


Three billion people, approximately half the world's population, depend on biomass fuels (wood, crop residue, animal dung, etc) as their primary domestic energy source (WHO 2002). Often, the combustion of these fuels is done indoors over open fires with little or no means of ventilation. Extended exposure to biomass emissions significantly increases the risk of acute respiratory infections, chronic bronchitis, and obstructive pulmonary disease (Bruce, Perez-Padilla et al. 2002). The World Health Organization (2002) estimates that poor indoor air quality associated with biomass fuel combustion is responsible for $2.7 \%$ of the global burden of disease. Women and children are especially vulnerable to the health risks associated with biomass fuel combustion and poor indoor air quality. In many parts of the world, traditional gender roles assign the responsibility of meal preparation and child care to women thus disproportionally exposing both to harmful emissions during cooking activities. Women and children comprise the majority of the 1.6 million annual deaths attributed to indoor air pollution. It is estimated that $56 \%$ of this total are children under the age of five (Warwick and Doig 2004).

In response, a growing number of governmental and non-governmental organizations have participated in initiatives to improve indoor air quality and reduce biomass fuel consumption. Interventions include improved ventilation, cleaner and more efficient fuel sources, and improved stoves that increase fuel economy and reduce emissions. Examples of potential intervention opportunities are shown in Figure $1-1$.

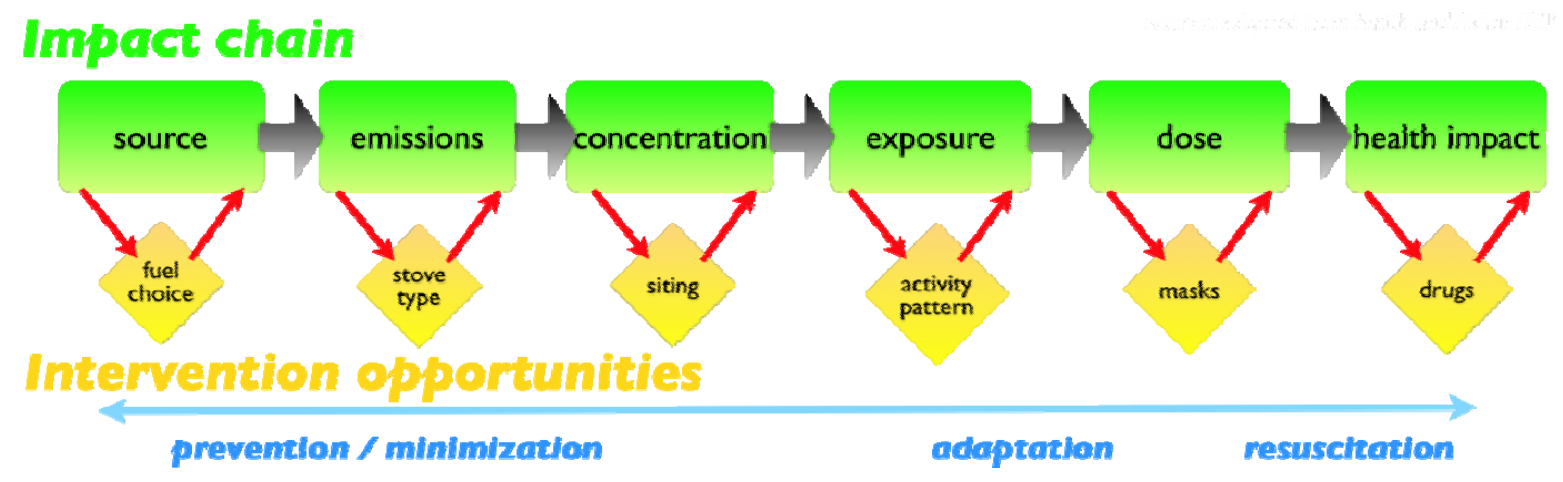

Figure 1-1 Intervention opportunities

Stove dissemination programs have been met with varying levels of success. As is true with any development initiative, the sustainability of an improved stove project is not driven by the technology alone. Social, cultural, and economic factors have a significant effect on stove use and adoption rates. The most successful improved stoves are easy to construct in local settings using existing techniques and materials and have clear advantages with respect to fuel economy, ease of use, durability, and cleanliness (Barnes 1994).

Mud stoves are one example of improved stove design. They combine high clay content soil with sand or an organic binder to form a stove body. Stove materials are of little or no cost and require few specialized tools or skills to construct. This makes them attractive in areas where there is little economic 
incentive to adopt an improved stove. However, these types of stoves are often criticized for the poor thermal and mechanical properties of the materials used and the negative effect this can have on stove performance and durability.

This study offers an analysis of earthen materials and their use in improved strove construction through performance testing mud stove design and a detailed analysis of material properties.

\subsection{PROJECT DEVELOPMENT}

The study of improved mud stoves developed during the two years the author spent as a U.S. Peace Corps volunteer in Mauritania and Mali, West Africa. The author served in Mauritania from 2008 to 2009 before the program was suspended due to security concerns. He spent the remainder of his service in neighboring Mali from 2009 to 2010. Both countries are in Africa's arid Sahel region to the south of the Sahara desert. Relevant national statistics for both Mauritania and Mali are given in Table $1-1$.

The project began in Mauritania as an attempt to reduce stress on local firewood sources through increased household fuel economy. In Mauritania, most cooking activities are performed outside and indoor air quality was not a significant concern. In Mali, however, a larger proportion of cooking is done indoors especially during the cold and rainy reasons. In this setting, increased emphasis was put on improving indoor air quality in addition to fuel efficiency.

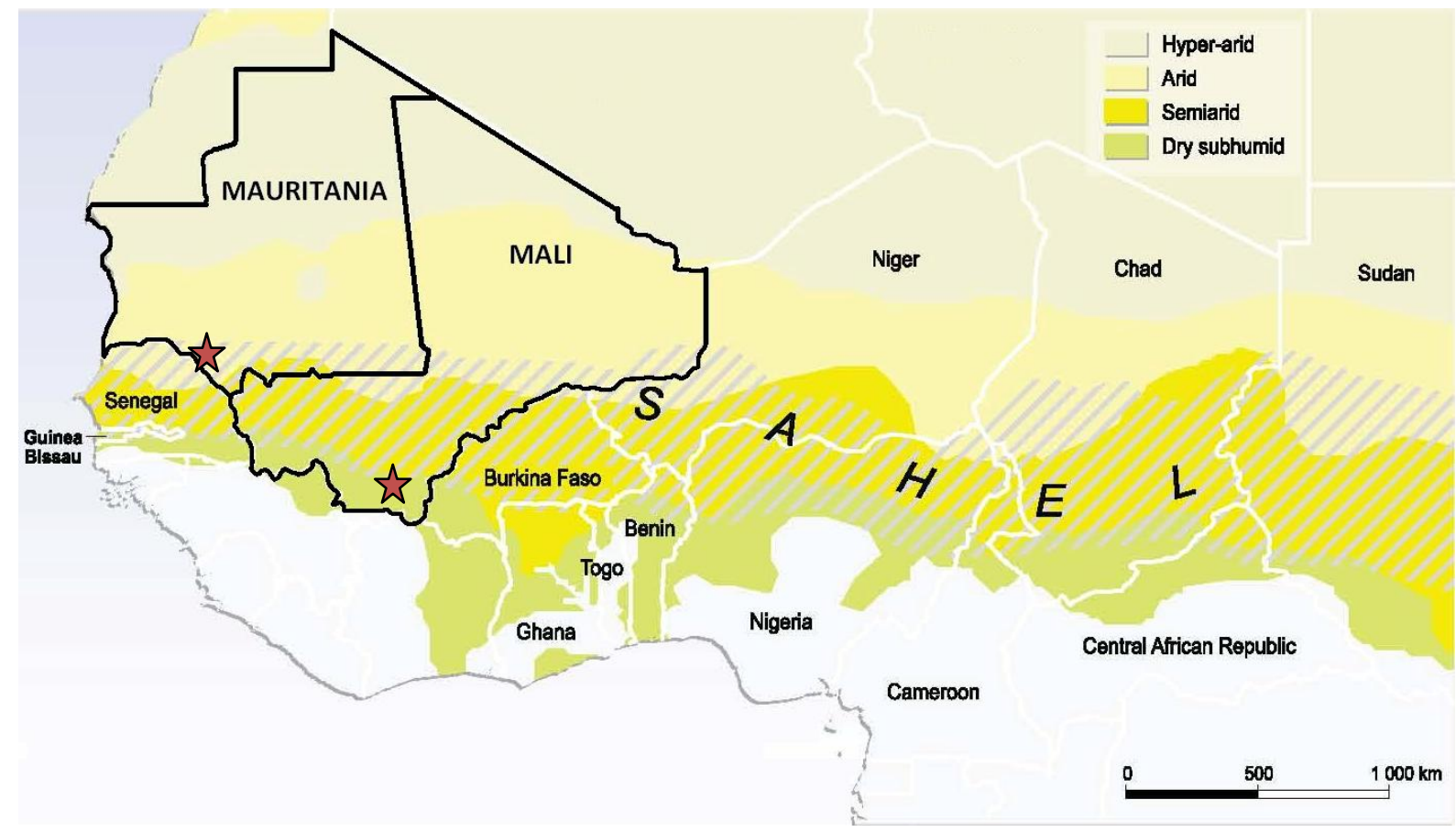

Figure 1-2 Project Site: Mauritania and Mali, Sahel Region of West Africa (Source: adapted from Millennium Ecosystem Assessment) 
Table 1-1 WHO Health Statistics for Mauritania and Mali (2008) (WHO Global Health Observatory Database)

\begin{tabular}{|l|c|c|}
\hline & Mauritania & Mali \\
\hline Total Poulation & $3,044,000$ & $11,968,000$ \\
Gross national income per capita (\$) & 1,970 & 1,000 \\
\hline $\begin{array}{l}\text { Life Expectancy (male / female) (years) } \\
\begin{array}{l}\text { Under-five mortality rate (probability of dying by age 5 per } \\
\text { Children births) } \\
\text { Respiratory Infection taken to a health facility (\%) }\end{array}\end{array}$ & $55 / 60$ & $45 / 48$ \\
\hline
\end{tabular}

Community members in both countries showed little interest in purchasing more advanced metal or ceramic stoves. They were, however, willing to gather materials and assist in the construction of mud stoves. Stoves were constructed on a household, basis using designs developed in Uganda by the the German Technical Cooperation (GTZ) and the Ugandan Ministry of Energy and Mineral Development (Uganda - GTZ 2004).

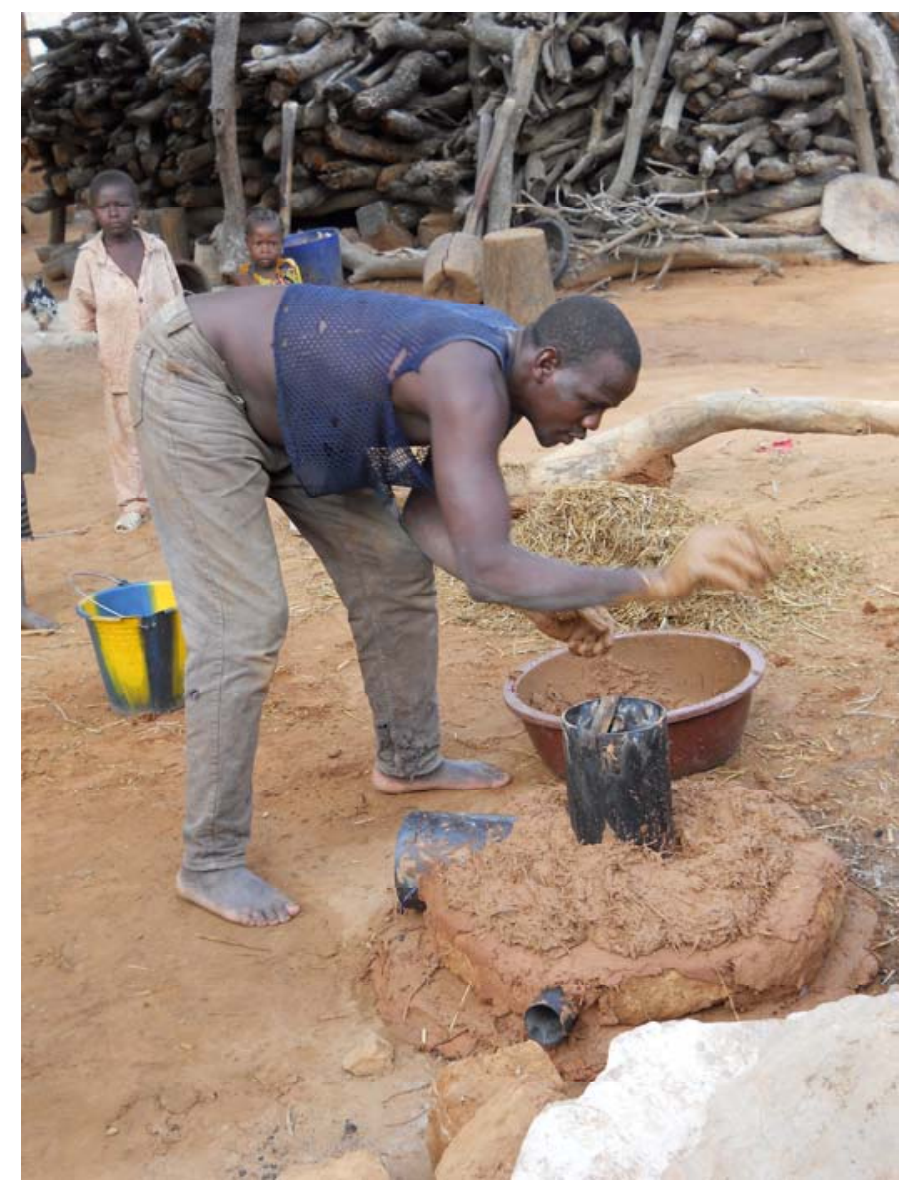

Figure 1-3 Stove construction in Mali (photo by author) 


\subsection{OBJECTIVES}

A qualitative assessment of stove design and performance, based on simple observations in the field, as well as feedback from users, prompted this more detailed analysis. With a better understanding of the capabilities of mud stoves and the suitability of earthen materials in stove construction, development workers in this region of West Africa and elsewhere who are interested in addressing indoor air quality and household energy use can make an informed decision on whether a mud stove is an appropriate intervention tool. The objectives of this analysis are are the following:

Objective 1: Evaluate mud stove performance with respect to thermal efficiency and emissions.

Objective 2: Evaluate the mechanical and thermal properties of mud stove material mixtures.

Objective 3: Provide suggestions for improvements to mud stove design using experimental data as well as feedback from stove users. 


\section{PROJECT BACKGROUND}

This chapter provides details on the scientific basis of biomass-burning stoves, several stove designs used in the developing world, and materials used.

\subsection{STOVE THEORY}

Improved stoves are designed to increase fuel efficiency and reduce smoke and harmful emissions associated with the combustion of biomass fuels. This is accomplished through improved thermal efficiency, a combination of enhanced combustion efficiency and heat transfer (Baldwin 1987). Combustion efficiency is the ratio of energy released during combustion to the total combustible energy potential of the fuel. Though poor combustion will negatively affect a stove's thermal performance, it is not as significant a factor as heat transfer efficiency. Energy losses due to inefficient or incomplete combustion typically account for less than $8 \%$ of total energy input (Baldwin 1987). However, the incomplete combustion of biomass fuels will produce harmful emissions. These include carbon monoxide (CO), unburned hydrocarbons (UHC), nitrogen oxides (NOx), smoke and soot (Ndiema, Mpendazoe et al. 1998).

Improved stove designs seek to increase combustion efficiency though a number of design features. Adequate draft and a proper air-to-fuel ratio ensure a more complete and efficient combustion process. Careful consideration of the size, geometry, and placement of the fuel inlet and combustion chamber provides increased control of airflow. A hotter fire is also more effective at consuming combustible gases. Proper insulation around the combustion chamber reduces heat loss, allowing the fire to burn at higher temperatures (Bryden, Still et al. 2005).

Stove heat transfer efficiency describes the amount of energy absorbed by the cook pot relative to the amount of energy released by the combustion process. When carefully controlled, even an open fire is capable of high combustion efficiency (Bussmann 1988). However, in an open fire, radiation is the main mechanism of heat transfer, and approximately $20-40 \%$ of its input energy is lost to the atmosphere as hot gas emissions. Utilizing these hot gases through effective convective heat transfer can significantly improve thermal efficiency (Baldwin 1987).

In an improved stove convection is the primary method of energy transfer between the moving combustion gases and the stationary surface of the cook pot. Convection consists of energy transfer though bulk fluid motion, advection, and the arbitrary motion of fluid molecules, conduction. Advection is the more effective mechanism of energy transfer and is proportional to the fluid velocity (Incropera 2007). Therefore, design features of improved stoves seek to maximize the velocity of the combustion gases as well as the pot surface area in contact with these gases.

\subsection{STOVE MATERIALS}

A significant disadvantage of an improved stove relative to an open cook fire is the body of the stove itself. Regardless of its material composition, the body of an improved stove provides a thermal mass that will conduct and store energy from the fire that might otherwise be transferred to the cook pot. Energy conduction into the stove body accounts for $14-42 \%$ of input energy, the largest of stove energy 
losses (Baldwin 1987). Selecting proper materials while minimizing the overall mass of the stove can reduce the amount of energy lost to the stove body.

The material thermal properties relevant to stove design are density $(\rho)$, thermal conductivity $(k)$, and specific heat $\left(c_{p}\right)$. Thermal conductivity describes the ability of a material to transfer energy through thermal diffusion. Specific heat or heat capacity is the ability of a material to store thermal energy and is typically proportional to material density (Incropera 2007). Under steady state conditions, thick, dense stove bodies of low thermal conductivity but high specific heat will conduct less energy from a fire than a thinner, less conductive body. However, it is unlikely this will compensate for the large amount of energy absorbed while the body warms. It is therefore advisable to use thin, low density materials in stove construction (Baldwin 1987).

Metals, although relatively lightweight and durable, are so conductive they can make lighting and maintaining fires difficult. Advanced stoves will incorporate insulative ceramics. The use of organic binders and a high temperature firing process, produce a lightweight, porous material. These low density materials have a low heat capacity and thermal conductivity because of the small voids left in the material structure by the firing process (Still, Pinnell et al. 2003)

Earthen materials, clay, sand, and rock, are not ideal for improved stove construction. These materials are dense and have a high heat capacity. Using them as part of a stove body is likely to divert energy away from the fire and the cook pot (Still and Roth 2010). However, earthen materials are low cost and readily available in most areas. Using these materials in improved stoves seldom requires specialized tools or complex construction processes. Simple modifications to earthen material mixtures can improve their mechanical and thermal properties, and make them a more suitable option for stove construction.

The Uganda-GTZ stoves are an example of earthen or mud stoves. These stoves combine high clay content soil and an organic binder to form the stove body. Binders can include straw, sawdust, cropresidue as well as wood ash and pumice. The addition of binders can improve a mixture's mechanical and thermal properties. Their fibrous nature improves material strength and durability. They also displace the clay matrix, reducing density, heat capacity, and thermal conductivity (Binici, Aksogan et al. 2007).

\subsection{ROCKET STOVES}

The rocket stove is an improved stove design developed by Larry Winiarski and the Aprovecho Institute. The stove incorporates an L-shaped combustion chamber and pot "skirt" to improve heat transfer and combustion efficiency during cooking activities. The combustion chamber consists of a horizontal fuel magazine and vertical internal chimney. Wood is fed horizontally into the fuel magazine ensuring even combustion from one end and a more easily regulated feed rate. The internal chimney creates draft, accelerating combustions gases from the fire. These gases are then forced through the skirt that surrounds the cook pot. Greater convective heat transfer is the result of improved advection and increased surface area contact (Bryden, Still et al. 2005). A schematic of a rocket stove can be seen in Figure 2-1. 


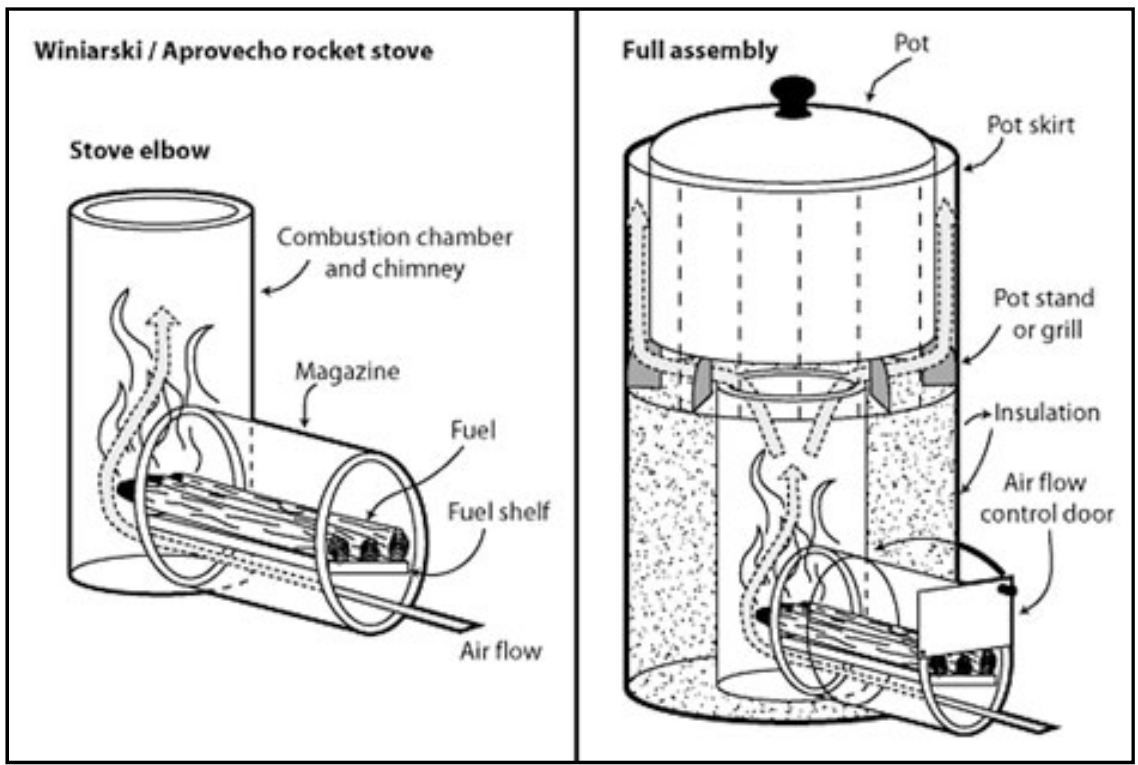

Figure 2-1 Rocket Stove (source: Aprovecho Institute)

\subsection{GTZ-UGANDA STOVES}

In cooperation with the Ugandan Ministry of Energy and Mineral Development, the German Technical Cooperation (GTZ) developed a design and dissemination program for two improved mud stove designs. As part of this project, the group distributed a design and construction guide, How to Build the Improved Household Stoves (2004). Variations on the two designs were constructed during field work in Mauritania and Mali. A third design, influenced by the Uganda-GTZ models, was also developed and implemented.

The first of these designs, the shielded fire stove, is a single-pot rocket stove. It incorporates the characteristic L-shaped combustion chamber with a pot skirt. The stove is custom built to the cook pot most frequently used in the household. Clay and straw or another appropriate binder are mixed and packed around an L-shaped form to construct the stove body and combustion chamber. The cook pot itself acts as the form for the pot skirt to insure an exact fit. A schematic of the shielded fire stove can be seen in Figure 2-2. 


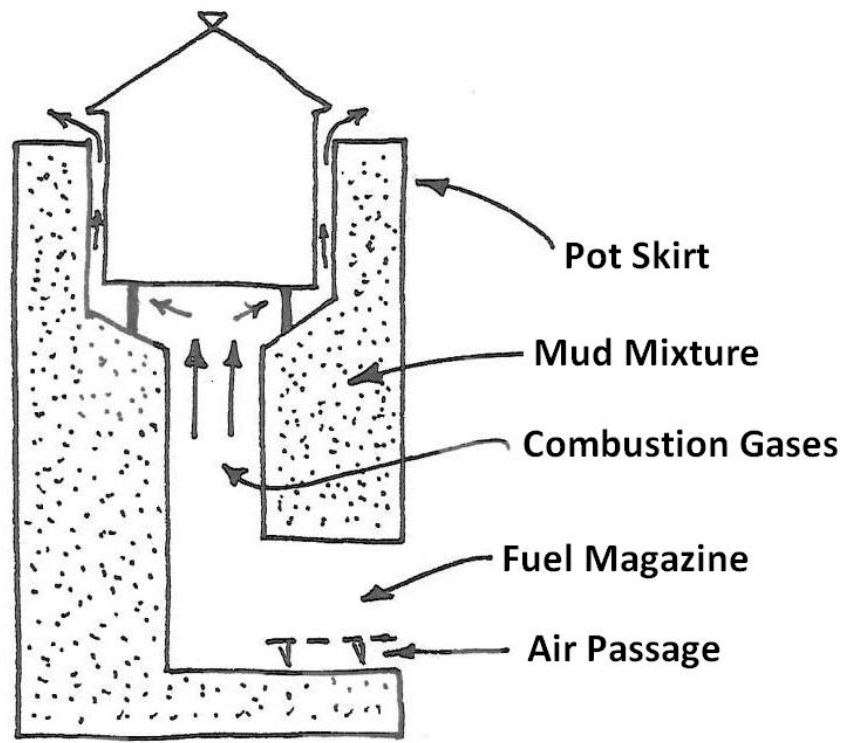

Figure 2-2 Shielded Fire Stove (source: adapted from Ministry of Energy and Mineral Development, Republic of Uganda and GTZ 2004)

The second design, a rocket-lorena mud stove, is a more advanced variation of the shielded fire stove. It incorporates the same L-shaped combustion chamber but includes space for two pots connected by channels and a chimney to remove smoke from the cooking space. It is constructed from the same mud mixture as the shielded fire stove and is also custom-built to the dimensions of the most frequently used cook pots. A schematic of the rocket-lorena stove is provided as Figure 2-3.

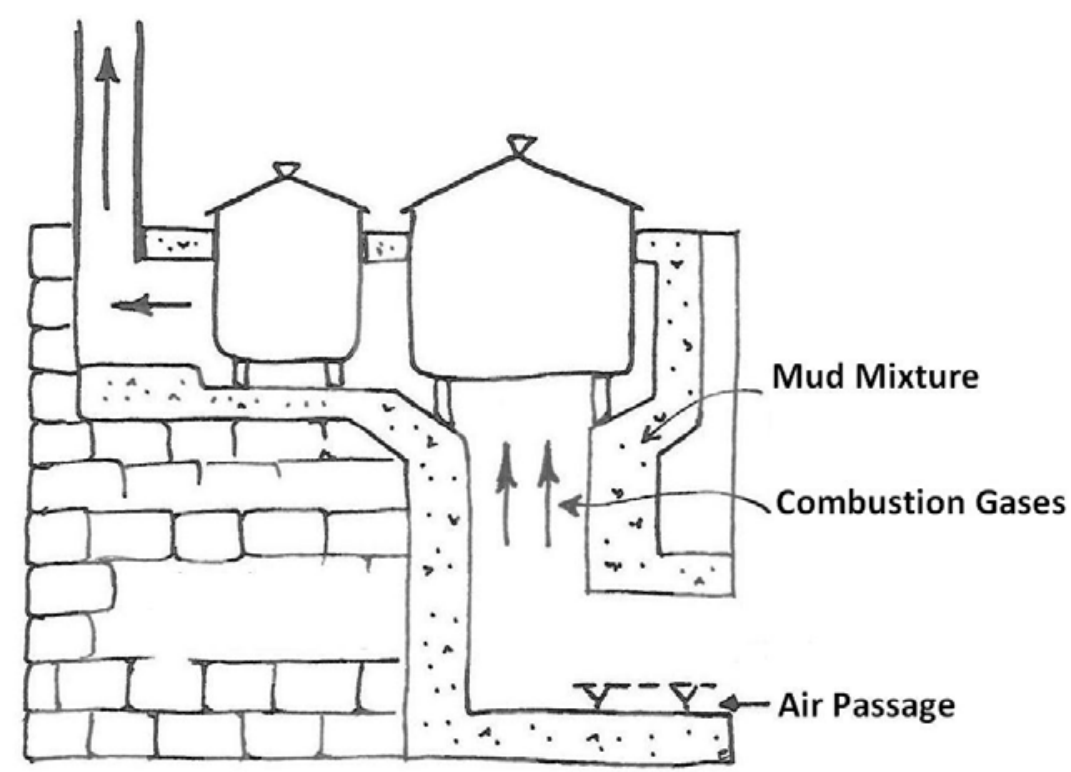

Figure 2-3 Rocket Lorena Stove (source: adapted from Ministry of Energy and Mineral Development, Republic of Uganda and GTZ 2004) 
The third design, a two pot shielded fire stove, is a variation on the shielded-fire and rocket-lorena stove and was developed by the author for implementation in Mali. It includes the same L-shape combustion chamber and channel connected pot seats as the rocket-lorena stove but has no chimney. The rounded body is similar to that of the shielded fire stove and is formed around the pots in same manner.

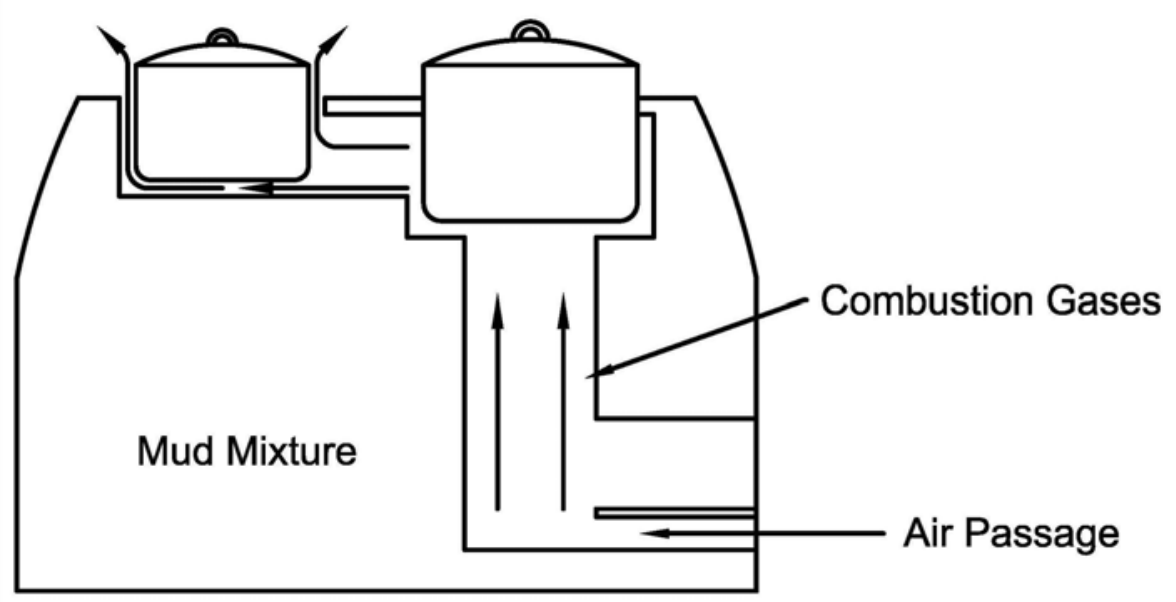

Figure 2-4 Two pot shielded fire rocket stove 
This chapter covers the methodologies used in this project, specifically project participant surveys, stove construction and testing, material testing, and thermal modeling.

\subsection{USER SURVEYS}

To gain a greater understanding of cooking practices in the project sites and to evaluate the performance of the improved mud stoves, user surveys were conducted with community members who showed interest in constructing an improved stove. Pre- and post-implementation surveys were conducted with the users of the two-pot rocket stove, while users of the rocket-lorena and single pot rocket stoves were surveyed only after stove implementation.

Survey participants were the women primarily responsible for cooking in each home. They were first approached and asked if they were interested in constructing an improved stove. If interest was exhibited, the pre-implementation survey was given. One month after stove construction was complete, the participants were given the post-implementation survey.

Surveys were administered orally by non-native but competent West African Bambara speakers. The user's understanding of the interviewers' translation of survey questions from English to Bambara was necessary to respond. In cases where comprehension was difficult, a third party was used to clarify questions and responses. All interview techniques were compliant with Michigan Technological University human subjects research guidelines.

The survey was a modified version of the qualitative user survey outlined in the Partnership for Clean Indoor Air's (PCIA) Kitchen Performance Test (2007). The Kitchen Performance Test survey includes questions not relevant to the type of stoves implemented in the project as well as several other questions related to socio-economic and gender issues. Although important, these were outside the scope of this study and were not used. Modifications were made to narrow the scope of the survey to cooking practices, fuel use, user satisfaction and user input. Table 3-1 shows the questions used in this abbreviated survey. 
Table 3-1 Cooking practices and improved stove survey

\begin{tabular}{|c|c|}
\hline Pre-Implementation Survey & Post-Implementation Survey \\
\hline $\begin{array}{l}\text { Questions } \\
\text { 1. Who is primarily responsible for cooking (age } \\
\text { and gender)? } \\
\text { 2. Is cooking done inside, outside, or both? } \\
\text { 3. Is the kitchen separate from the main house? } \\
\text { 4. What kind of stove(s) is used? How } \\
\text { frequently? } \\
\text { 5. Whose job is it to obtain cooking fuel (age } \\
\text { and gender)? } \\
\text { 6. Where is cooking fuel obtained? How far is it } \\
\text { from the household? } \\
\text { 7. What kinds of pots are used? } \\
\text { 8. Are pot-lids used for cooking } \\
\text { 9. What does the primary cook dislike about } \\
\text { current cooking arrangements? } \\
\text { 10. Is the family interested in using an improved } \\
\text { stove? }\end{array}$ & $\begin{array}{l}\text { Questions } \\
\text { 1. How long has the family been using the stove? } \\
\text { 2. How often does the family use the stove? } \\
\text { 3. What kinds of pots are being used in the new } \\
\text { stove? } \\
\text { 4. Does the family use any other kinds of stoves } \\
\text { in addition to the improved stove? } \\
\text { 5. Is it easier or more difficult to cook with the } \\
\text { new stove? Why? } \\
\text { 6. Do meals take longer to prepare using the } \\
\text { new stove? } \\
\text { 7. Are there any cooking tasks easier to } \\
\text { accomplish with the new stove? } \\
\text { 8. What does the cook like most about the } \\
\text { stove? } \\
\text { 9. Is there anything that the cook would change } \\
\text { about the new stove? }\end{array}$ \\
\hline $\begin{array}{l}\text { Observations } \\
\text { 1. What types of stove(s) is present in the } \\
\text { kitchen? } \\
\text { 2. Is there any evidence for successful } \\
\text { participation in an improved stove project? }\end{array}$ & $\begin{array}{l}\text { Observations } \\
\text { 1. What types of stoves are present in the } \\
\text { kitchen? } \\
\text { 2. Does the stove appear as if it has been used } \\
\text { recently? } \\
\text { 3. Does it appear as if other stove(s) are also } \\
\text { being used? What kind of stove(s)? } \\
\text { 4. What kind of fuel is being used (species, } \\
\text { size)? }\end{array}$ \\
\hline
\end{tabular}




\subsection{STOVE CONSTRUCTION}

A single-pot, shielded-fire rocket stove was constructed for laboratory-based performance testing at Michigan Technological University. Procedures and design criteria presented in the Ugandan Ministry of Energy and Mineral Development and GTZ publication How to Build the Improved Household Stoves (2004) were followed during the stove construction process. Following the design guide, critical stove dimensions were dictated by the size and geometry of the primary cook pot to be used during stove operation.

Because weighing instruments are not readily available when constructing stoves in the field, stove materials, clay and straw, were mixed by hand on a one-to-one volume basis. Dry materials were mixed in batches and water was added until the mixture reached a workable consistency.

Sections of 16-cm diameter PVC pipe were used as forms for the fuel inlet and combustion chamber. The clay and straw mixture was placed by hand around the PVC pipe to from the stove body. The cook pot itself was used as the form for the pot skirt. The clay and straw mixture was placed in the same manner as the combustion chamber to a thickness of seven centimeters. When the pot was removed, a small gap was cut in the material to form the outlet for combustion gases. To ensure stability, the process was conducted in two stages over two days, allowing lower sections of the stove to dry for 24 hours before additional material was added. The stove was allowed to dry for four weeks prior to testing.
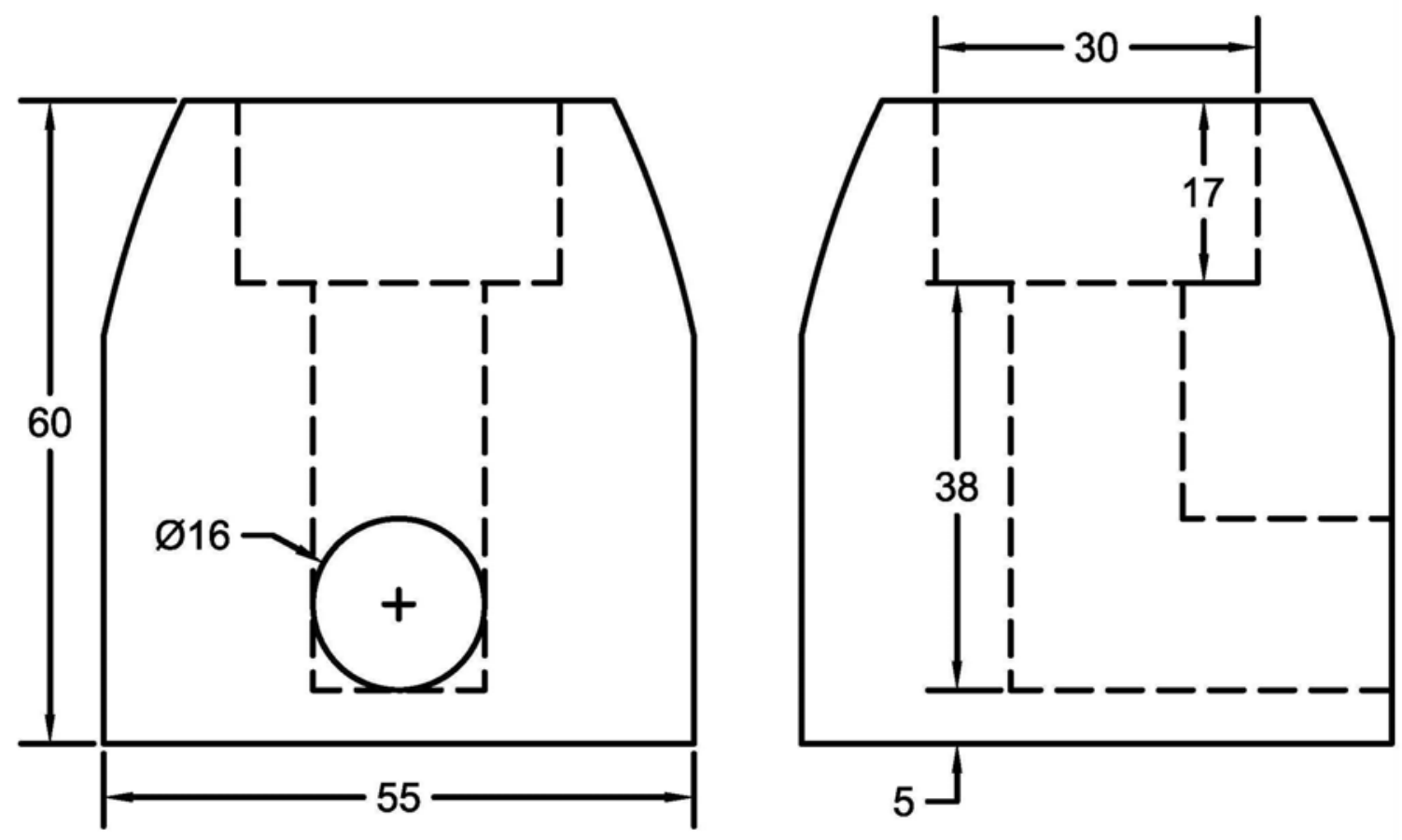

Figure 3-1 Schematic of shielded fire rocket stove constructed for laboratory performance and emissions testing (All dimensions in centimeters) 


\subsection{STOVE PERFORMANCE TESTING}

The procedures outlined in the Water Boiling Test (WBT) from the Partnership for Clean Indoor Air (2007) were used to evaluate the thermal performance of the stove. This test evaluates a stove during three separate phases of operation: cold-start, warm-start, and simmer. During the test, the amount of time and fuel required to bring a measured volume of water to a boil, as well as hold it at a simmer, were recorded to determine overall stove efficiency.

Three complete runs of the WBT were conducted in an enclosed space under a fume hood in the foundry of the Materials and Metallurgy Building on the Michigan Technological University campus. The equipment used included a type $\mathrm{K}$ thermocouple and data logger to monitor and record water temperature and a mass balance to measure the amount of fuel used.

During stove construction, thermocouples were also placed in the stove body to measure the temperature distribution between the combustion chamber and the outside wall of the stove. Three type-K thermocouples (Omega Engineering Inc. Stamford, CT) were placed just inside the wall of the combustion chamber, at the mid-point of the stove body, $10 \mathrm{~cm}$ from the inside wall, and at the outside stove wall, $20 \mathrm{~cm}$ from the inside wall. Temperature measurements were taken continuously during stove operation, and recorded every ten seconds.

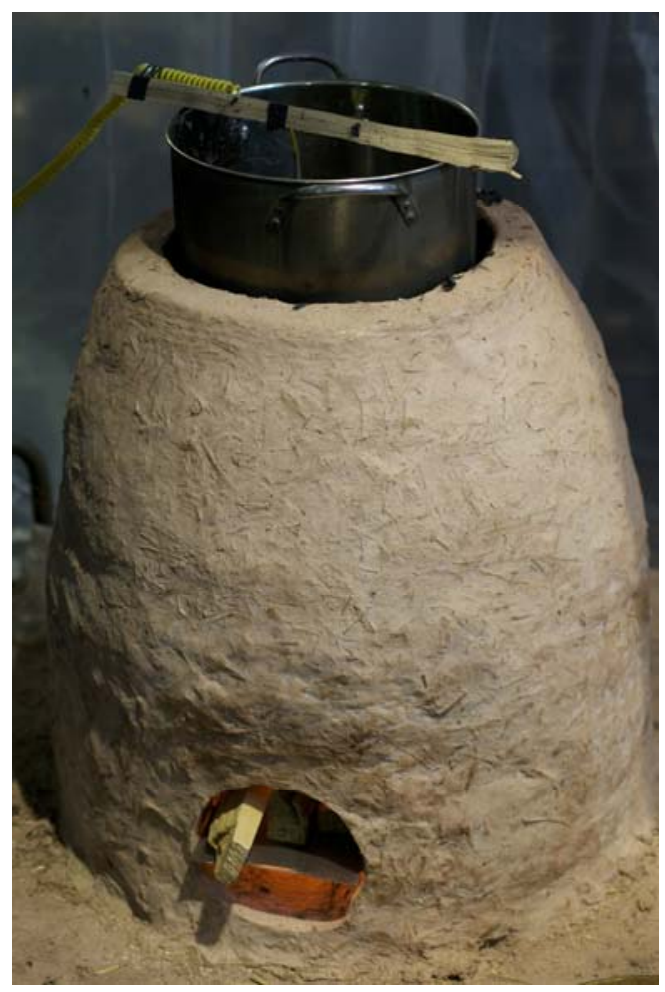

Figure 3-2 Shielded fire stove during a Water Boiling Test for $1 \mathrm{~L}$ of water in a $30 \mathrm{~cm}$ diameter pot 


\subsection{STOVE THERMAL MODELING}

To model temperature distribution and heat loss in the stove body during operation, a one dimensional, ten-node finite difference model was used. The model was originally developed by Andreatta in his report Heat Loss from Stoves: Thermal properties of insulative bricks (2003) and was adapted to run in MATLAB. A copy of the MATLAB script is available in Appendix_A.

The model inputs include: the relevant thermal properties of the stove materials, stove dimensions, and the ambient environmental conditions during stove operation. Assumptions included a constant combustion gas temperature and ideal convection and radiation heat transfer at the wall of the combustion chamber and the outside surface of the stove.

The model predicted temperature as a function of operation time at ten evenly spaced nodes inside the stove wall. The positions of the sixth and tenth nodes corresponded to the positions of the thermocouples present in the stove body during performance testing. Temperature data collected during multiples test runs at these points were used when calibrating the model and checking for accuracy. Total energy loss to the stove body was also predicted from a summation of the temperature at each node multiplied by the material's specific heat and the total mass of the stove body.

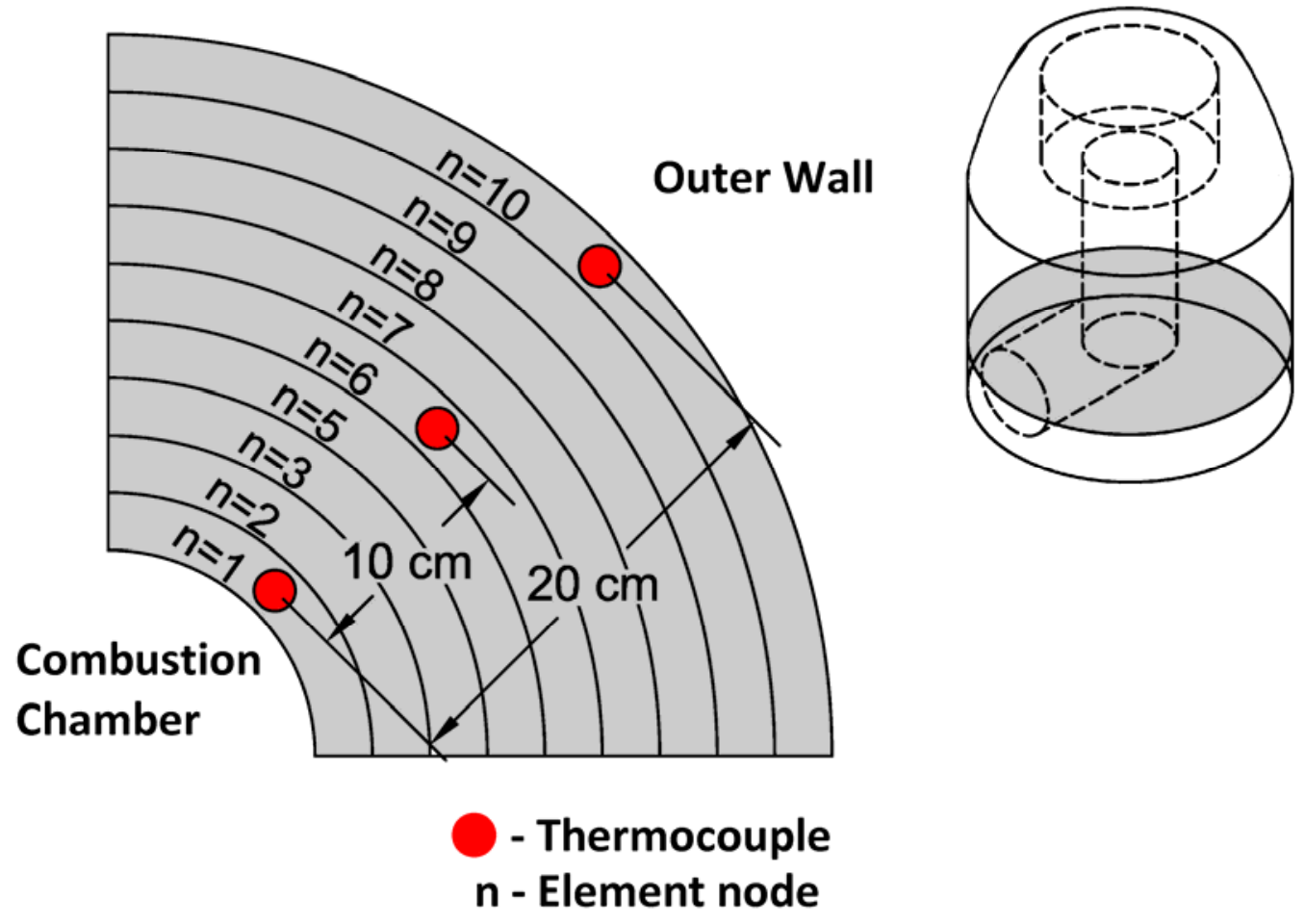

Figure 3-3 Thermocouple placement and computational element nodes in the stove body 


\subsection{MATERIALS TESTING}

\subsubsection{Specific heat}

The specific heat of the clay and straw mixture was measured using a calorimeter. Small samples, 3 to 5 $\mathrm{cm}$ in diameter, were prepared. After measuring their mass, each sample was placed in an oven until they reached a temperature of approximately $120^{\circ} \mathrm{C}$. When removed from the oven, samples were placed in an insulated container containing a measured volume of water. The system was allowed to reach equilibrium and the temperature of the water was measured.

Because the system is insulated, it was assumed that the energy lost from the sample was equal to the energy gained by the water, and the steady-flow thermal energy equation can be applied. Where $q$ is energy in Joules, $\mathrm{m}$ is mass in $\mathrm{kg}, \mathrm{C}_{\mathrm{p}}$ is specific heat in $\mathrm{J} / \mathrm{kg} \cdot \mathrm{K}$, and $\mathrm{T}$ is temperature in Kelvin.

$$
\begin{aligned}
& q=m c_{p}\left(T_{f}-T_{i}\right) \\
& m_{\mathrm{H}_{2} \mathrm{O}} C_{p, \mathrm{H}_{2} \mathrm{O}}\left(T_{f}-T_{i, \mathrm{H}_{2} \mathrm{O}}\right)=m_{\text {sample }} C_{p, \text { sample }}\left(T_{i, \text { sample }}-T_{f}\right) \\
& C_{p, \text { sample }}=\frac{m_{\mathrm{H}_{2} \mathrm{O}} C_{p, \mathrm{H}_{2} \mathrm{O}}\left(T_{f}-T_{i, \mathrm{H}_{2} \mathrm{O}}\right)}{m_{\text {sample }}\left(T_{i, \text { sample }}-T_{f}\right)}
\end{aligned}
$$

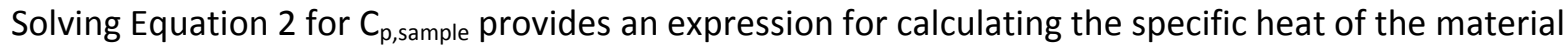
mixture as shown in Equation 4 (Incropera 2007).

$$
C_{p, \text { sample }}=\frac{m_{\mathrm{H}_{2} \mathrm{O}} C_{p, \mathrm{H}_{2} \mathrm{O}}\left(T_{f}-T_{i, \mathrm{H}_{2} \mathrm{O}}\right)}{m_{\text {sample }}\left(T_{i, \text { sample }}-T_{f}\right)}
$$

\subsubsection{Thermal conductivity}

The clay and straw stove mixture is neither an isotropic nor a homogenous material. Definitively quantifying thermal conductivity can be difficult for this type of material. Instead two methods were used to provide a range of appropriate values.

The first method used principles of one-dimensional, steady state conduction through planar objects. In this system, a sample of the material was stacked in series with a section of foam insulation of known thermal conductivity (Figure 3-4). Thermocouples were placed on either end and between the two objects. The sample and the section of insulation were then placed between a large pot of water at ambient temperature and a block of ice. These served as heat sinks for the system and remained at relatively constant temperature, the water near room temperature and the ice near freezing. The system was allowed to reach steady state conditions and the temperature differential across the materials was recorded.

Because the temperature of the water and the ice remain at constant temperatures, the heat flux is assumed to be one dimensional at the center and constant through both the sample and the section of foam insulation. Using the measured temperature differential across the insulation and across the sample the thermal conductivity can be determined. 
An adaptation of Fourier's law of conductive heat transfer given the parameters of this system provides an expression for the heat flux (Equation 5).

$$
q^{\prime \prime}=\frac{k_{1}\left(T_{1}-T_{2}\right)}{L_{1}}=\frac{k_{2}\left(T_{2}-T_{3}\right)}{L_{2}}
$$

Where $\mathrm{q}^{\prime \prime}$ is heat flux per unit area $\mathrm{W} / \mathrm{m}^{2}, \mathrm{~L}$ is the material thickness in $\mathrm{m}, \mathrm{k}$ is thermal conductivity in $\mathrm{W} / \mathrm{m} \cdot \mathrm{K}$, and $\mathrm{T}$ is temperature in Kelvin. Solving the equation for $\mathrm{k}_{2}$ provides an expression for calculating thermal conductivity (Incropera 2007).

$$
k_{2}=\frac{k_{1} L_{2}\left(T_{1}-T_{2}\right)}{L_{1}\left(T_{2}-T_{3}\right)}
$$

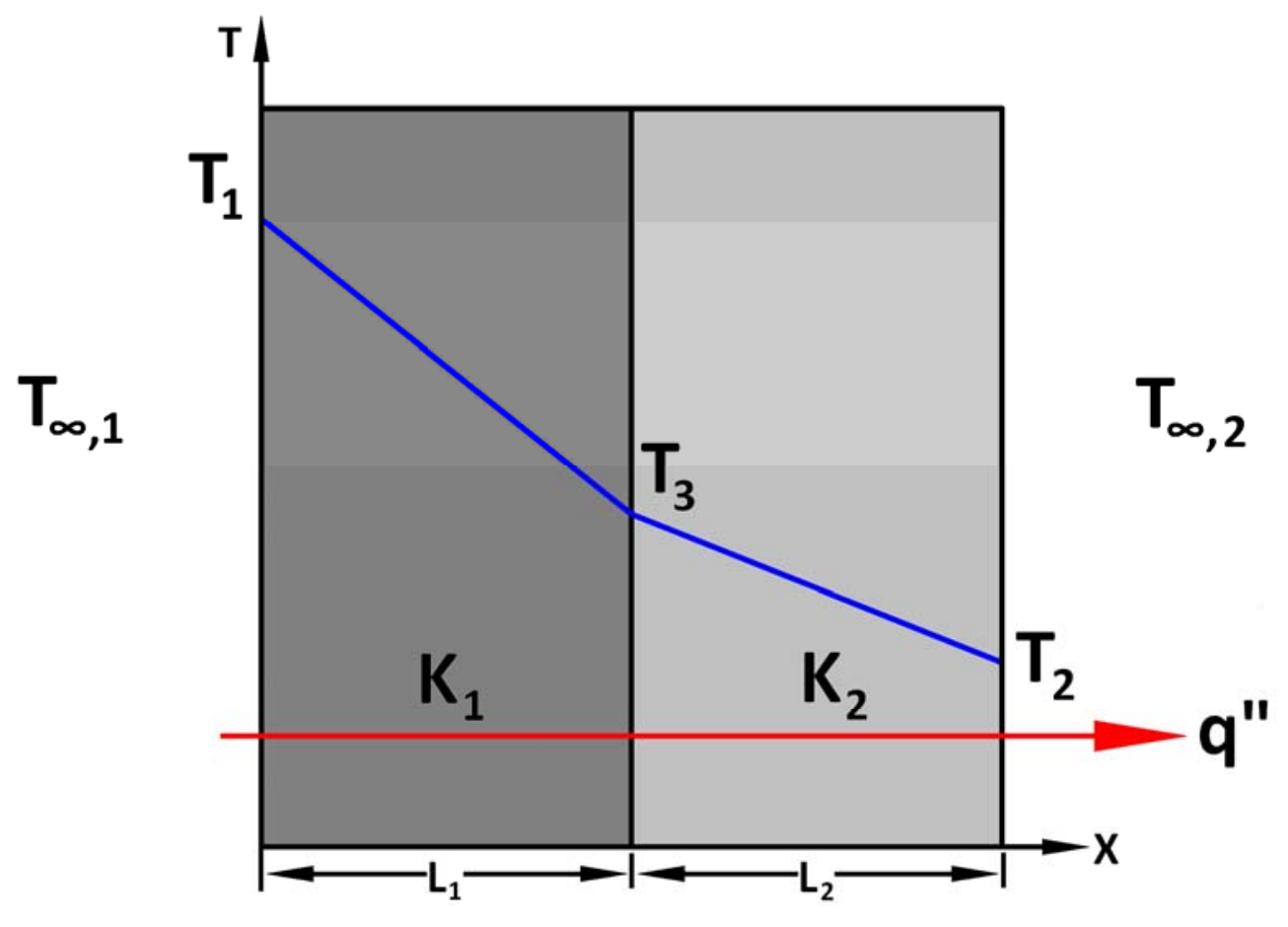

Figure 3-4 Conductive heat transfer through a series of planar objects of varying thermal conductivity

The second method used the MATLAB computer model described above. The model required values for material density and specific heat in addition to thermal conductivity. Having previously determined density and specific heat, thermal conductivity was allowed to vary. The model was then calibrated to the temperature data collected using a root mean square deviation approach. 


\subsubsection{Compression strength}

Compression strength of the clay straw mixture was measured using samples prepared in concrete molds. The samples measured approximately $10 \mathrm{~cm}$ in diameter and $20.5 \mathrm{~cm}$ in length. Cylinders were allowed to cure for a period of at least 30 days prior to testing. Test cylinders were loaded until failure, on a Warner and Swasey Compression Test Press and the average of the recorded peak loads were used to determine the overall compressive strength.

\subsection{STOVE EMISSIONS TESTING}

Stove emissions were measured in conjunction with stove thermal performance testing. The observed pollutants were carbon monoxide $(\mathrm{CO})$, carbon dioxide $\left(\mathrm{CO}_{2}\right)$, and particulate matter at or below 2.5 micrometers in aerodynamic diameter (PM2.5). A TSI QTrak air quality monitor (TSI, St. Paul, MN) was used to measure $\mathrm{CO}$ and $\mathrm{CO}_{2}$ concentrations at intervals of 30 seconds. Measurements of PM2.5 concentrations were taken with a TSI DustTrak monitor set to record at intervals of one minute. Both air quality monitors were factory calibrated before their use in this study. Measurements were taken continuously during all three phases of all three full experimental runs of the PCIA Water Boiling Test.

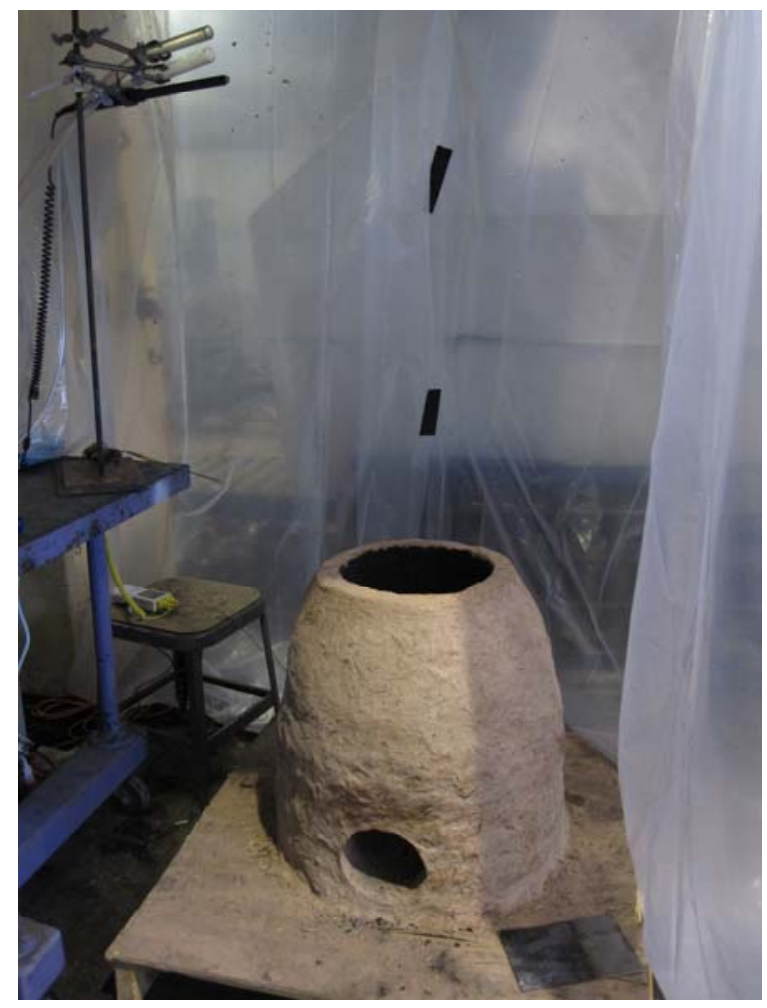

Figure 3-5 Emissions sampling set up during stove testing; instrument sampling inlets were positioned $1 \mathrm{~m}$ above pot atop stove 


\subsection{USER SURVEY RESPONSES}

User responses to the administered survey provided context to stove construction activities as well as constructive feedback relevant to viable stove design improvements. In pre-implementation surveys, participants gave insight into typical cooking practices and fuel use. Cooking activities and fuel gathering are done almost exclusively by women. Travel of up to seven kilometers is required to obtain adequate firewood. Cooking is done primarily indoors over three stone fires. Users appreciated the portability and the ease of use of a traditional three stone fire, but were dissatisfied with the amount of smoke and poor fuel economy.

In post-implementation surveys, participants critiqued the shielded fire rocket stove, rocket-lorena stove, and two pot shielded fire rocket stove. Responses pertaining to design features common to all three stove types were considered for design improvements. These are discussed in greater detail in Chapter 6: Design Suggestions.

\subsection{STOVE PERFORMANCE CHARACTERISTICS}

Results of the Water Boiling Test for the shielded fire stove can be seen in Table 4-1. The results are separated into the three sections representing each phase of the test, high power (cold start), high power (hot start), and low power (simmer).

A single value of thermal efficiency derived from a combination of the test phases is not an adequate indicator of stove performance because it does not consider the production of steam. Thermal efficiency indicates how effective heat energy from the fire is transferred to the cook pot. High thermal efficiency may also coincide with the production of excess steam. Energy carried away by steam cannot be utilized in the cooking process (Balis, Ogle et al. 2007). For this reason specific fuel consumption is also presented as the amount of fuel consumed per unit output or in this case, the amount of wood burned to boil one liter of water.

Other metrics include firepower, simply a representation of how quickly the stove releases energy from fuel, and turndown ratio, the relationship between the power outputs during the high power phases of the test and the lower power, simmer phase. Values shown as temperature corrected are adjusted to a standard $75^{\circ} \mathrm{C}$ temperature change $\left(25^{\circ}\right.$ to 100$)$. This allows for comparisons between stoves tested under different ambient environmental conditions. 
Table 4-1 Shielded fire water boiling test results. The Water Boiling Test was conducted in three phases, high power cold start, high power hot start, and simmer to evaluate the stove under varying operating conditions. The duration of the first two phases was dependent on the time needed to bring 2.5 liters of water to boil. The third, low power phase was 45 minutes in duration. During this time water was kept just below boiling to simulate slow cooking operations. Values shown as temperature corrected are adjusted to a standard $75^{\circ} \mathrm{C}$ temperature change $\left(25^{\circ}\right.$ to 100$)$.

\begin{tabular}{|l|c|c|c|c|}
\hline SHIELDED FIRE STOVE & units & $\begin{array}{c}\text { HIGH POWER } \\
\text { (COLD START) }\end{array}$ & $\begin{array}{c}\text { HIGH POWER } \\
\text { (HOT START) }\end{array}$ & $\begin{array}{c}\text { LOW POWER } \\
\text { (SIMMER) }\end{array}$ \\
\hline Time to boil & $\min$ & 25.3 & 15.2 & - \\
Temp-corrected time to boil & $\min$ & 24.2 & 14.5 & - \\
Burning rate & $\mathrm{g} / \mathrm{min}$ & 27.1 & 26.7 & 25.4 \\
Thermal efficiency & $\%$ & $13 \%$ & $18 \%$ & $21 \%$ \\
Specific fuel consumption & $\mathrm{g} /$ liter & 289.3 & 171.5 & 20556.7 \\
Temp-corrected consumption & $\mathrm{g} /$ /iter & 276.6 & 163.1 & - \\
Energy Input & $\mathrm{MJ}$ & 11.2 & 7.0 & 19.4 \\
Firepower & watts & 7771 & 7656 & 7283 \\
Turn down ratio & - & - & - & 1.08 \\
\hline
\end{tabular}

The increasing trend in the thermal efficiency and decreasing trend in specific fuel consumption of the shielded fire stove between phases of the test suggests a significant amount of heat loss to the stove body. As the test begins, the stove body is at ambient temperature and a significant amount of energy is lost while it warms. Though the stove body is not especially conductive, its mass and specific heat capacity are significant enough to absorb and retain heat that might otherwise be used to heat the cook pot. Efficiency increases as the stove body reaches higher temperatures and less energy is absorbed.

As a means of comparison, the results of a cold start test for a traditional three stone fire are presented in Table 4-2. The test was performed only once and is not meant to be statistically valid, but it does provide a simple benchmark for comparison. 
Table 4-2 Comparison of shielded fire stove and three stove fire performance results

\begin{tabular}{|l|c|c|c|}
\hline HIGH POWER (COLD START) & units & $\begin{array}{c}\text { THREE STONE } \\
\text { FIRE }\end{array}$ & $\begin{array}{c}\text { SHIELDED FIRE } \\
\text { STOVE }\end{array}$ \\
\hline Time to boil & min & 49.6 & 25.3 \\
Temp-corrected time to boil & min & 46.1 & 24.2 \\
Burning rate & g/min & 14.2 & 27.1 \\
Thermal efficiency & $\%$ & $18 \%$ & $13 \%$ \\
Specific fuel consumption & g/liter & 367.3 & 289.3 \\
Temp-corrected consumption & g/liter & 341.4 & 276.6 \\
Energy Input & MJ & 12.1 & 11.2 \\
Firepower & watts & 4078 & 7771 \\
\hline
\end{tabular}

A comparison of the performance data shows that, in a cold start scenario, a three-stone fire will outperform the shielded fire stove with respect to thermal efficiency, although it does take much longer to reach boiling temperature. At later phases, the shielded fire stove does offer a small improvement in thermal efficiency and specific fuel consumption. Overall, the shielded fire stove is at a significant disadvantage due to the mass of its stove body and offers little improvement over a three-stone fire with respect to thermal efficiency.

\subsection{STOVE BODY HEAT LOSS AND THERMAL DISTRIBUTION}

Stove body temperature data collected during the first and second run of the Water Boiling Test suggest the material mixture is of low thermal conductivity but relatively high specific heat capacity. The plotted data in Figure 4-1 and Figure 4-2 show the temperature gain at three points inside the stove wall. In both the runs, the temperature in the middle of stove body does not begin to increase significantly for the first 30 minutes of the test. It then increases exponentially for the remainder of the run, indicating slow thermal conduction followed by thermal absorption and storage.

The temperatures at the mid-point of the stove body predicted by the numerical heat loss model are compared to the measured values during the first and second runs of the water boiling test are also shown in Figure 4-1 and Figure 4-2. The model used measured values of density, specific heat, and a varying value of thermal conductivity that was calibrated to fit the output to the measured temperature data. The mixture material properties used in the model are presented in Table 4-4.

The numerical model was also used to estimate total heat loss into the stove body for all three runs of the Water Boiling Test. In Table 4-3 heat loss is expressed as a percentage of total energy input. Design changes that reduce wall thickness and overall stove mass should result in reduced heat loss to the stove body and an increase in thermal efficiency. 


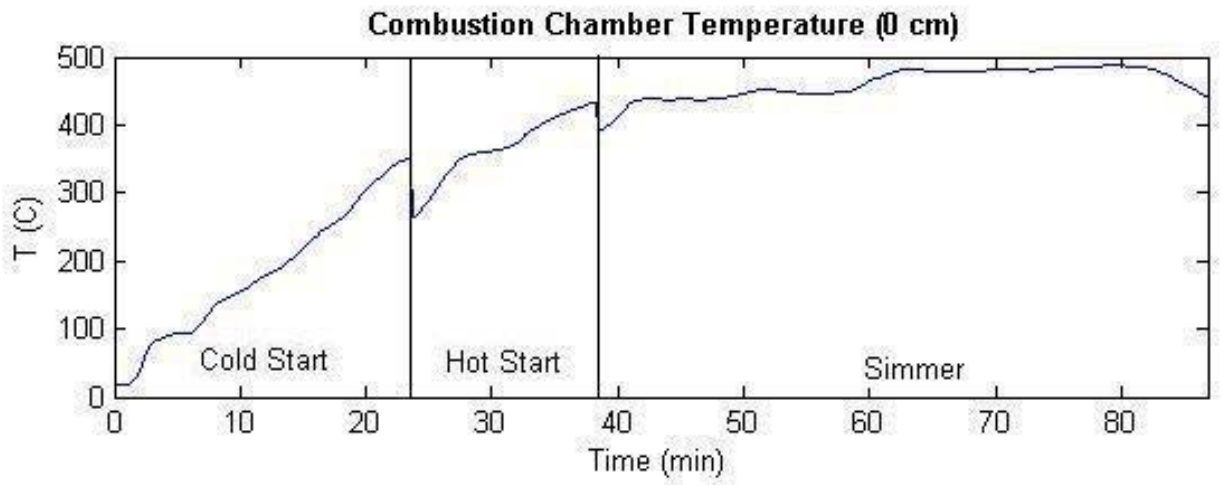

Midpoint Temperature $(10 \mathrm{~cm})$

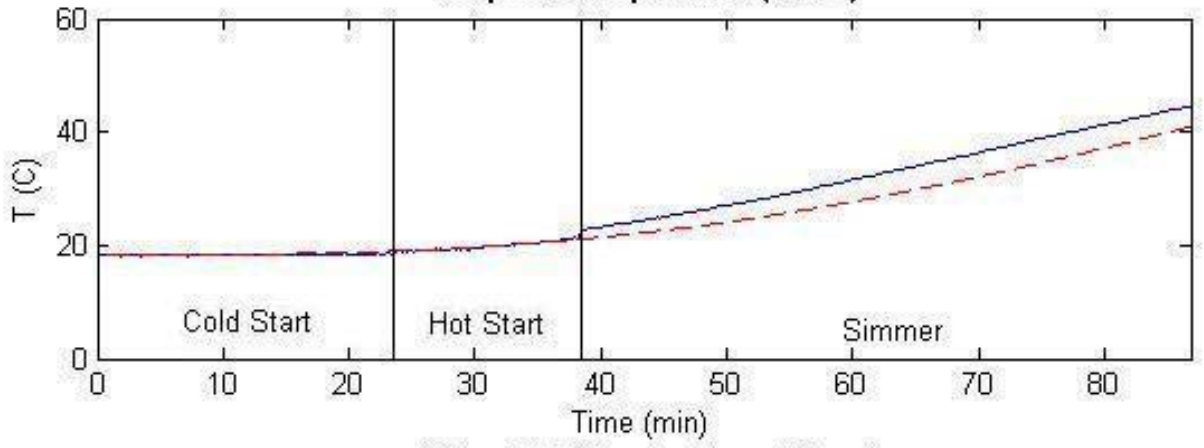

Outer Wall Temperature $(20 \mathrm{~cm})$

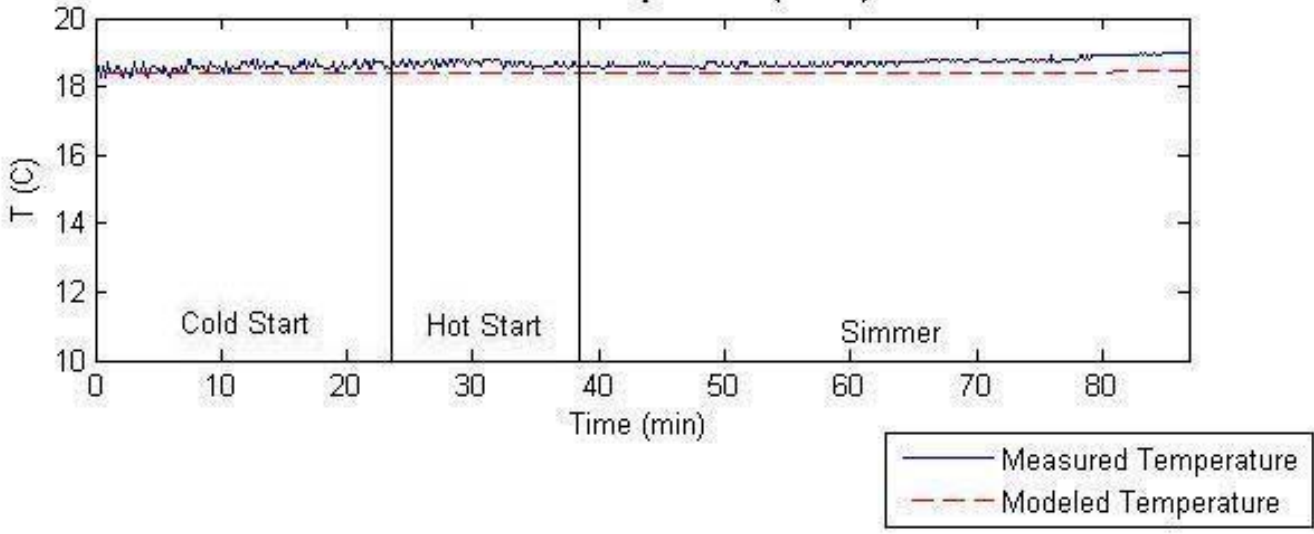

Figure 4-1 Stove body temperature distribution (Water Boiling Test: Run 1) 


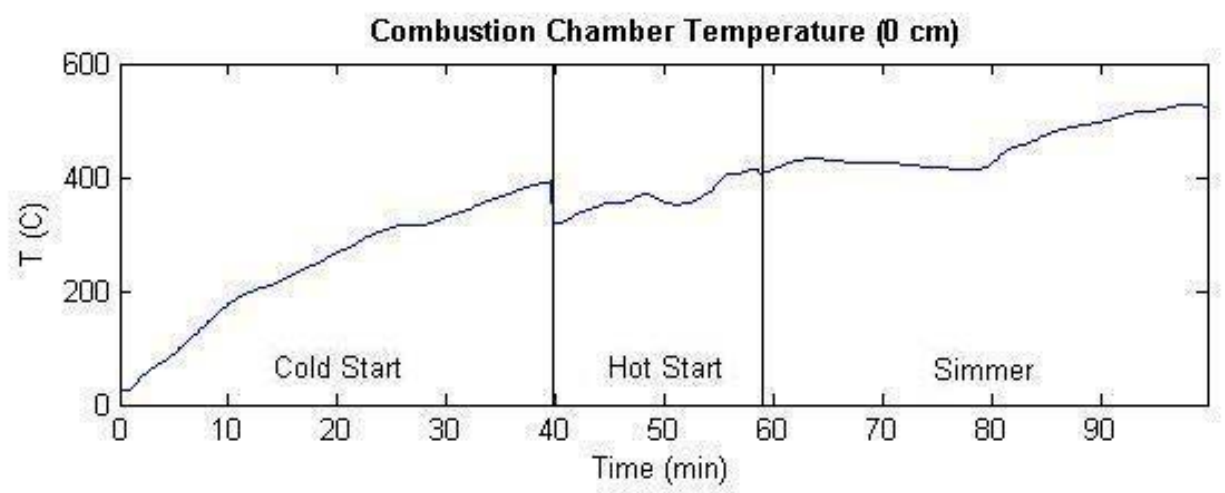

Midpoint Temperature $(10 \mathrm{~cm})$

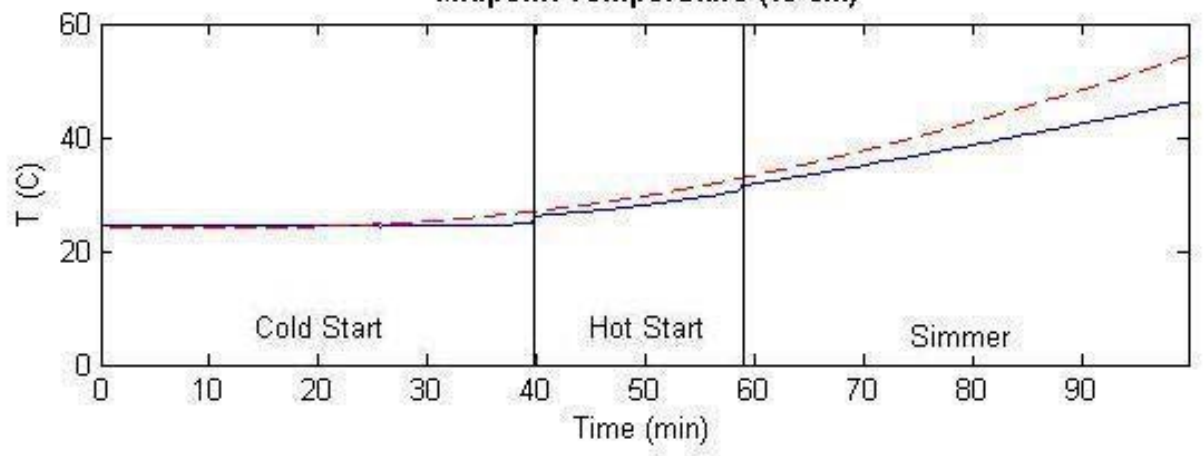

Outer Wall Temperature $(20 \mathrm{~cm})$

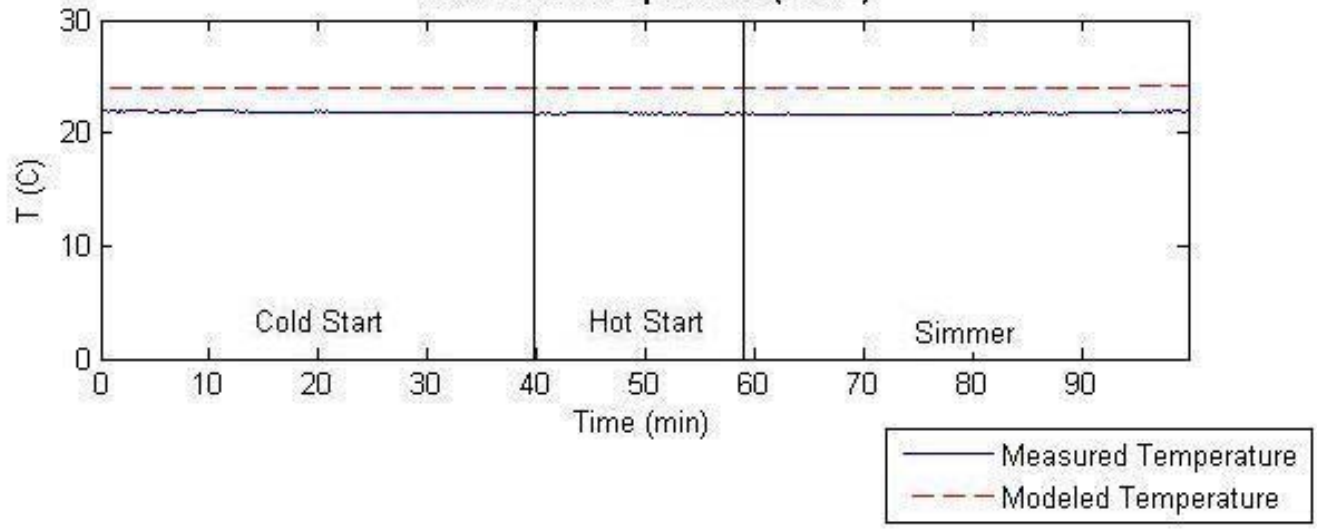

Figure 4-2 Stove body temperature distribution (Water Boiling Test: Run 2)

Table 4-3 Heat loss to stove body relative to total energy input

\begin{tabular}{|lcccc|}
\hline & Units & WBT Run 1 & WBT Run 2 & WBT Run 3 \\
\hline Energy Input & MJ & 33.19 & 41.72 & 37.75 \\
Energy Loss to Stove Body & MJ & 3.74 & 3.99 & 3.66 \\
Percent of Energy Input & $\%$ & 11.3 & 9.6 & 9.7 \\
\hline
\end{tabular}




\subsection{MATERIAL PROPERTIES}

The relevant thermal and mechanical properties of the clay and straw mixture are given in Table 4-4. Thermal properties for fired ceramics and other materials that have been used in the construction of combustion chambers and improved stove bodies are also included for comparison in Table 4-5. Glass wool is included to represent an ideal insulator but it is likely impractical for stove construction.

With respect to thermal properties, the clay-straw mixture is comparable to clay with sawdust and clay with vermiculite bricks. If the clay-straw mixture was exposed to a similar firing process, it is likely the thermal properties would improve further. Combustion as a result of stove operation, as well as breakdown due to natural decomposition over time, might also consume some of the straw in a manner similar to a firing process. This would reduce density and improve the material's thermal properties.

Table 4-4 Mud mixture material properties

\begin{tabular}{|lcc|}
\hline Density $(\rho)$ & 881 & $\mathrm{Kg} / \mathrm{m}^{3}$ \\
\hline Specific Heat $\left(C_{\mathrm{p}}\right)$ & 881 & $\mathrm{~J} / \mathrm{Kg} \mathrm{K}$ \\
\hline Thermal Conductivity $(\mathrm{k})$ & $0.062-0.142 \mathrm{~W} / \mathrm{m} \mathrm{K}^{2}$ \\
\hline Compressive Strength $(\sigma)$ & 1.45 & $\mathrm{~N} / \mathrm{mm}^{2}$ \\
\hline
\end{tabular}

Table 4-5 Thermal properties of common combustion chamber materials (Andreatta 2003)

\begin{tabular}{|l|ccc|}
\hline Material & $\begin{array}{c}\text { Density } \\
(\mathrm{kg} / \mathrm{m} 3)\end{array}$ & $\begin{array}{c}\text { Specific Heat } \\
(\mathrm{J} / \mathrm{Kg}-\mathrm{K})\end{array}$ & $\begin{array}{c}\text { Thermal Conductivity } \\
(\mathrm{W} / \mathrm{m}-\mathrm{K})\end{array}$ \\
\hline Ordinary Brick & 1600 & 840 & 0.700 \\
\hline Guatamalan Baldosa & 1691 & 812 & 0.219 \\
\hline $\begin{array}{l}85 \% \text { pearlite 15\% clay } \\
\text { (760 C firing temperature) }\end{array}$ & 439 & 921 & 0.128 \\
\hline 50/50 sawdust/clay & 729 & 701 & 0.081 \\
\hline $85 \%$ vermiculite 15\% clay & 559 & 698 & 0.120 \\
\hline El Coco Baldosa & 1328 & 835 & 0.181 \\
\hline Pumice brick & 770 & 835 & 0.107 \\
\hline Glass wool & 40 & 700 & 0.038 \\
\hline
\end{tabular}

\subsection{STOVE EMISSIONS}

From the data collected by emissions monitoring equipment during performance testing of the shielded fire stove, moving averages of pollutant concentrations over all three complete runs of the water boiling test were determined. Plots of $\mathrm{CO}_{2}, \mathrm{CO}$, and PM2.5 are given in Figure 4-3, Figure 4-4, and Figure 4-5 respectively. Plot of $\mathrm{CO}$ and PM2.5 concentrations for a cold start test of three stone fire are also shown in Figure 4-6 and Figure 4-7 respectively. 


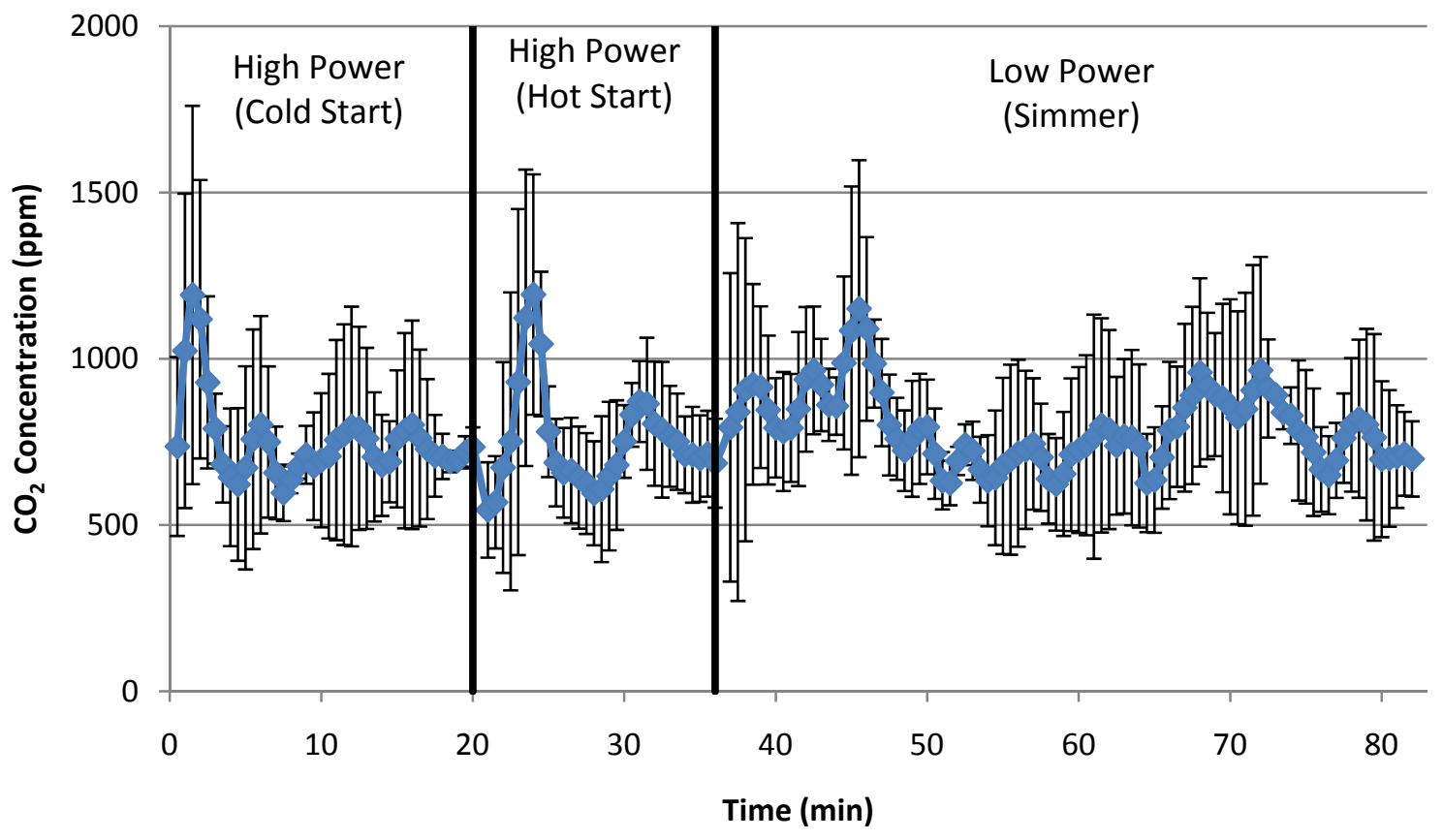

Figure 4-3 Averages of $\mathrm{CO}_{2}$ concentration of shielded fire stove emissions over three complete runs of the Water Boiling Test (WBT). Errors bars represent one standard deviation above and below mean values.

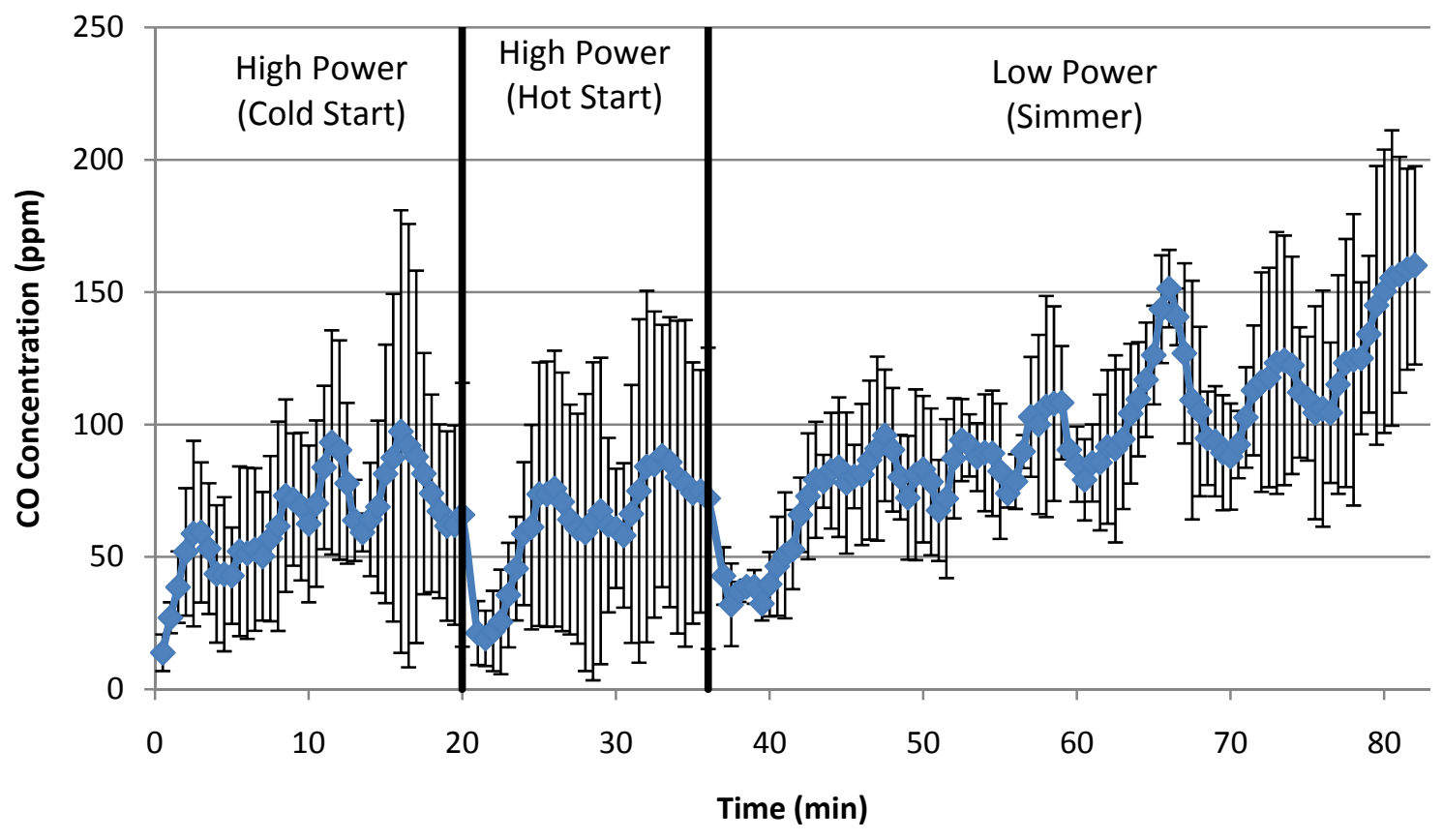

Figure 4-4 Averages of $\mathrm{CO}$ concentration of shielded fire stove emissions over three complete runs of the Water Boiling Test (WBT). Errors bars represent one standard deviation above and below mean values. 


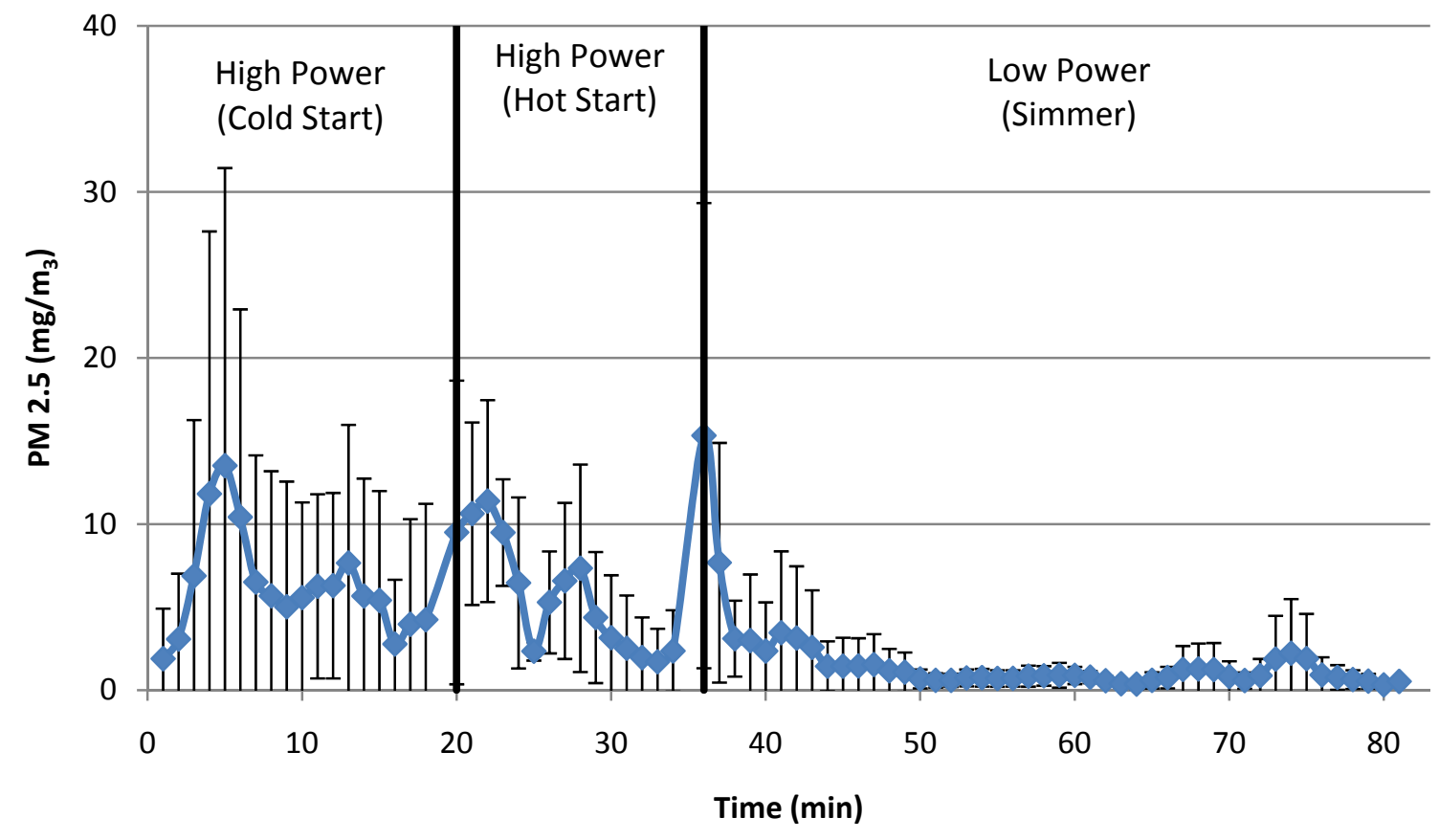

Figure 4-5 Averages of PM 2.5 concentration of shielded fire stove emissions over three complete runs of the Water Boiling Test (WBT). Errors bars represent one standard deviation above and below mean values.

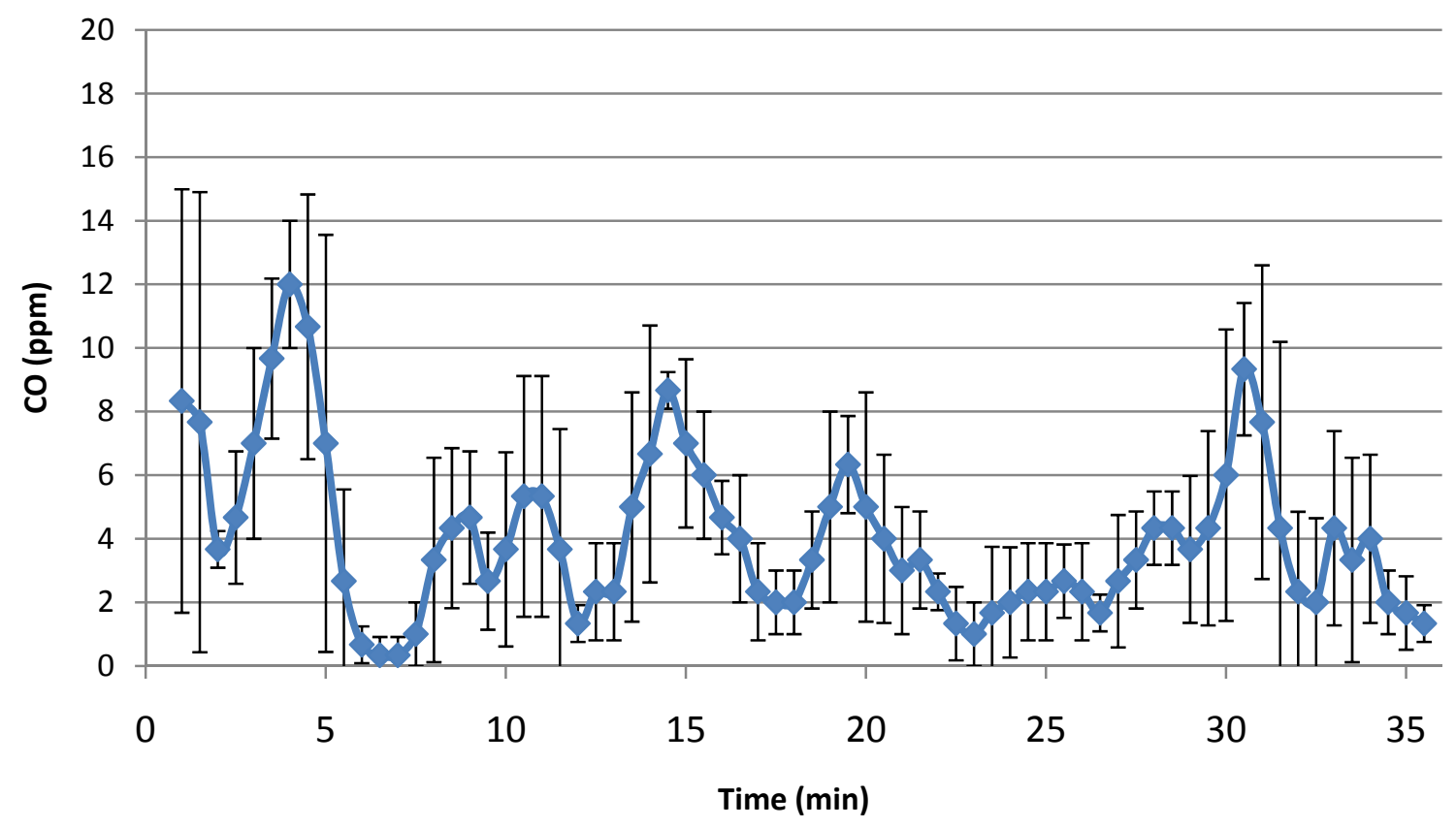

Figure 4-6 Moving average of PM 2.5 concentration of three stone fire emissions during one cold start test. Errors bars represent one standard deviation above and below mean values. 


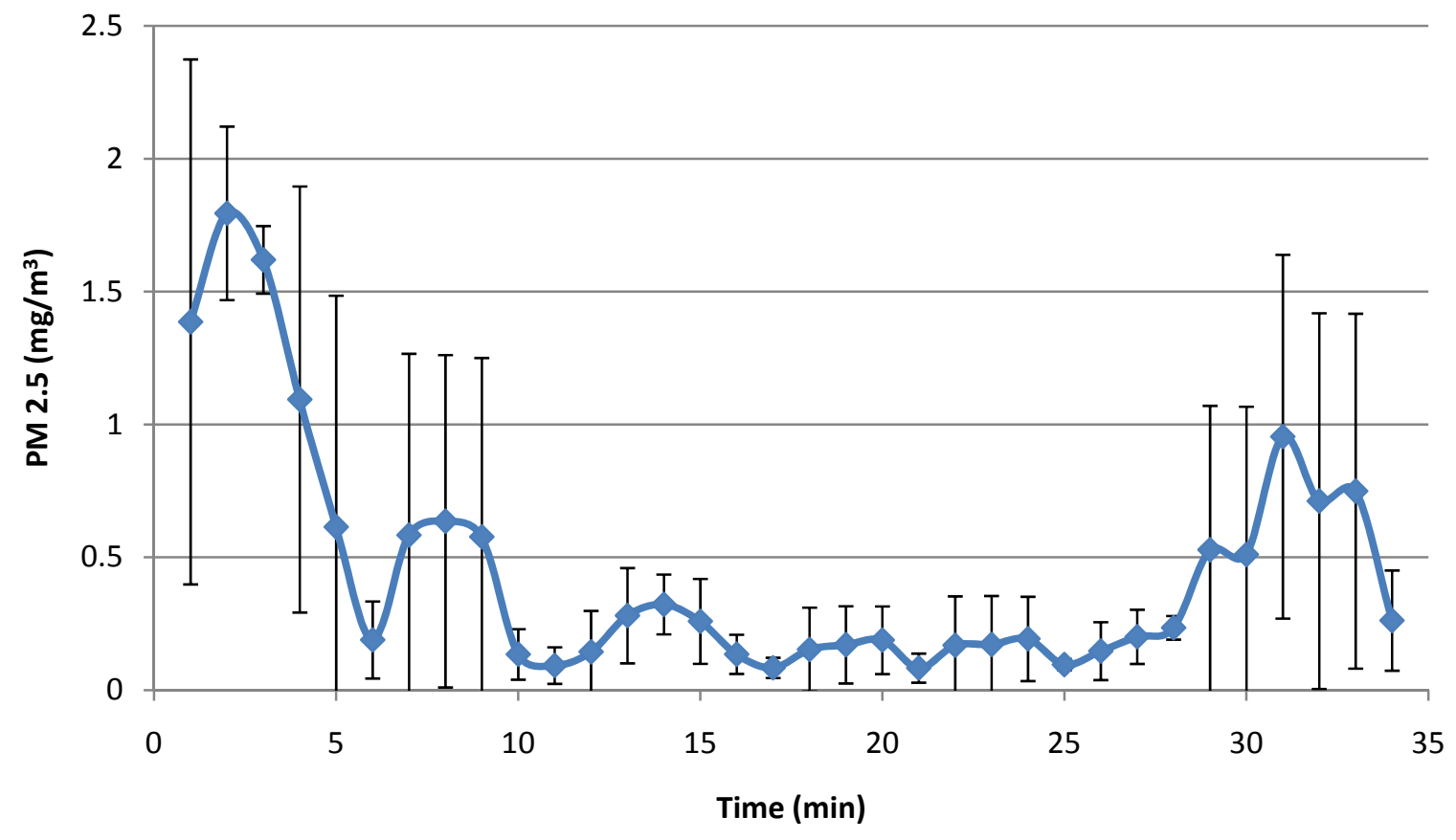

Figure 4-7 Moving average of PM 2.5 concentration of three stone fire emissions during one cold start test. Errors bars represent one standard deviation above and below mean values.

With an overall median value of $757 \mathrm{ppm}$, the $\mathrm{CO}_{2}$ concentrations in the shielded fire stove emissions do not vary appreciably through the phases of the Water Boiling Test. Relative to other indoor air pollutants, the adverse health effects associated with extended exposure to $\mathrm{CO}_{2}$ are low but can include eye, nose and throat irritation, mental fatigue and headache. $\mathrm{CO}_{2}$ concentrations in normal indoor environments vary from 350 to 2500 ppm (Seppänen, Fisk et al. 1999). Concentrations measured in the shielded fire stove emissions did not exceed this range.

An increasing trend in CO concentration can be observed through the progression of the WBT. CO is a product of incomplete combustion and despite the increased efficiency at later stages of the test, $\mathrm{CO}$ concentrations continued to rise. A similar rise in $\mathrm{CO}$ emissions during improved stove operation was observed in Ndiema, Mpendazoe et al. 1998. However, the authors observed an eventual peak and subsequent decline in $\mathrm{CO}$ concentrations after the stove had been operating for period of approximately 25 minutes. This may correspond to the stove body reaching a constant temperature and peak operating efficiency. The large mass of the shielded fire mud stove and subsequent energy absorption prevented it from reaching a constant temperature and a steady state condition.

Carbon monoxide is absorbed easily into the blood. It can impair a person's ability to function but presents the greatest threat to those with cardiovascular problems (Mihelcic, Zimmerman et al. 2010). The median $\mathrm{CO}$ concentration during stove testing was 80 ppm. The U.S. Environmental Protection Agency (EPA) ambient air quality standards are $35 \mathrm{ppm}$ for one hour of exposure and $9 \mathrm{ppm}$ for eight hours of exposure. $\mathrm{CO}$ emissions from the shielded fire stove also significantly exceeded those of the three stone fire which had a median value of $3 \mathrm{ppm}$. 
PM2.5 concentrations decreased steadily during stove operation. Spikes in the plotted data correspond to fire ignition at the start of test phases or the addition of new fuel. Particulate matter is also a product of incomplete combustion. The data suggests that stove efficiency has a greater effect on particulate matter emissions than on $\mathrm{CO}$ emissions.

Find particulate matter can cause significant damage to the respiratory system (Mihelcic, Zimmerman et al. 2010). The median PM 2.5 concentration during stove testing was $1.96 \mathrm{mg} / \mathrm{m}^{3}$ compared to 0.21 $\mathrm{mg} / \mathrm{m}^{3}$ for the three stone fire. The EPA standard sets $35 \mu \mathrm{g} / \mathrm{m}^{3}$ and $15 \mu \mathrm{g} / \mathrm{m}^{3}$ as recommended PM2.5 concentration limits for exposure periods of 24 hours and one year respectively. It is clearly evident why cooking on such stoves results in considerable irritation in the short term and respiratory impacts in the long term. 
Objectives of any improved stove project should be local viability, economic feasibility, and desirability. Mud stoves are not an ideal stove solution. More advanced stoves offer greater fuel economy and more significant improvement in biomass emissions. However, when technical, material, and financial resources are limited, mud stoves may be an appropriate solution, and despite their disadvantages certain improvements can be made. With information gathered from the performance analysis of the GTZ-Uganda shielded fire stove, the evaluation of mud mixture material properties, and responses from users in post-implementation surveys, design suggestions for mud stove builders were developed.

In this study and others it has been observed that unventilated improved stoves (stoves without a chimney or other direct means of smoke removal) might not appreciably decrease combustion emissions despite an increase in thermal efficiency. In fact, in some cases certain emissions might actually increase during the operation of an improved stove versus an open fire. Ahuja, Joshi et al (1987) noted a decrease in total suspended particulate emissions but an increase in carbon monoxide emissions for the more efficient stoves evaluated in their study. High levels of $\mathrm{CO}$ were also observed in cook stove emissions by Ndiema, Mpendazoe et al. (1998) as well as this study.

Ideally, an unventilated or chimney-less improved stove will be used outside or in a well-ventilated indoor space separate from living quarters. However, this is not always the circumstances under which improved stoves are implemented and operated. If significant improvements to stove emissions are not possible due to certain design constraints, as may be the case when using simple earthen materials in stove construction, it may be advisable to put increased focus on improving thermal efficiency. In addition to reducing biomass fuel use, increased efficiency might also reduce cooking time and the user's length of exposure to combustion emissions. This would require further observations with users in the field as no laboratory analysis could adequately simulate traditional cooking practices.

Stove height is one design parameter that can be adjusted to improve thermal efficiency. The GTZUganda shielded fire stove design guide suggests a stove body and internal combustion chamber height 2.5 times the height of the fuel inlet. In their evaluation of rocket stove operating variations, Hudelson et al. (2002) observed an increasing trend in thermal efficiency with a reduction in stove height. Combustion efficiency may suffer as combustible gasses have a reduced amount of space for secondary and more complete combustion, but reducing the stove height will put the pot in closer proximity to the fire thus increasing radiative heat transfer.

Stove users also took issue with stove height in post-implementation surveys. In Mali the staple dish is a corn flour based mixture called toh. During preparation, toh requires rigorous stirring for it to solidify. A taller stove and a raised pot height would make preparation easier as the user does not have to bend over as far; yet, Malians disliked the added height and preferred a lower pot height while cooking.

A smaller inlet diameter results in increased efficiency and lower combustion gas loses (Hudelson, Bryden et al. 2002). This was a point of contention between stove designers and stove users in Mauritania and Mali. Traditionally large diameter wood was collected for cook fires as it tends to burn for longer periods of time before additional wood is needed. Attempts to suggest a smaller stove inlet diameter and the use of smaller fuel were met with resistance. The inability to burn large pieces of wood was a complaint seen in several post implementation surveys. If potential stove users are receptive to using smaller fuel size then reducing the stove's inlet diameter is advisable. It is also recommended that a constant cross-sectional area be maintained between the stove inlet and the 
internal combustion chamber. Any modifications made to the inlet diameter should be applied to the combustion chamber diameter as well.

Table 5-1 and the corresponding diagram in Figure 5-1 show stove inlet and combustion chamber dimensions based on the cook pot diameter. The data is modified from the GTZ-Uganda guide to show adjusted design parameters. As PVC pipe or other materials will be used as temporary construction forms, it may be advisable to select inlet and combustion chamber dimensions that most closely match locally available materials.

Table 5-1 Inlet and combustion chamber dimensions based on cook pot diameter. $D$ is the inlet diameter, $\mathrm{H}$ is the height of the combustion chamber, $\mathrm{K}$ is the distance from the top of the fuel inlet to the outlet of the combustion chamber, and $\mathrm{L}$ is the pot skirt gap (modified from Ministry of Energy and Mineral Development, Republic of Uganda and GTZ 2004).

\begin{tabular}{|c|c|c|c|c|c|}
\hline $\begin{array}{c}\text { Pot Diameter } \\
(\mathrm{cm})\end{array}$ & $\begin{array}{c}\text { Inlet / Combustion } \\
\text { Chamber Diameter } \\
(\mathrm{D})(\mathrm{cm})\end{array}$ & $\begin{array}{c}\text { Chamber } \\
\text { Area }\left(\mathrm{cm}^{2}\right)\end{array}$ & $\mathrm{K}=\mathrm{D} / 2(\mathrm{~cm})$ & $\mathrm{H}=\mathrm{K}+\mathrm{D}(\mathrm{cm})$ & $\begin{array}{c}\text { Pot Skirt Gap } \\
(\mathrm{L})(\mathrm{cm})\end{array}$ \\
\hline$? 20$ & 12.0 & 113 & 6.00 & 18.00 & 1.6 \\
$21-27$ & 14.0 & 154 & 7.00 & 21.00 & 1.5 \\
$28-30$ & 16.0 & 201 & 8.00 & 24.00 & 2.0 \\
$31-35$ & 16.0 & 201 & 8.00 & 24.00 & 1.5 \\
$36-40$ & 18.0 & 254 & 9.00 & 27.00 & 1.9 \\
$41-45$ & 18.0 & 254 & 9.00 & 27.00 & 1.6 \\
$46-50$ & 20.0 & 314 & 10.00 & 30.00 & 1.9 \\
\hline
\end{tabular}

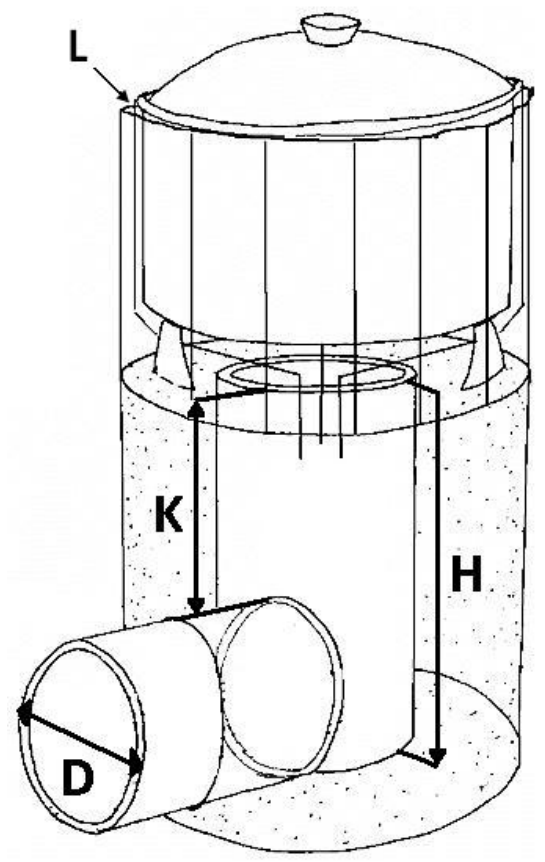

Figure 5-1 Stove inlet and combustion chamber dimensions (source: adapted from Aprovecho Institute) 
Significant heat loss into the stove body was observed during stove testing as well as in the numerical temperature distribution and heat loss model. Reducing the overall mass of the stove will decrease the amount of energy conducted and stored in the stove body. In addition to reducing overall stove height, wall thickness should also be minimized. When custom sizing a stove body to the dimensions of the user's cook pot, the GTZ-Uganda shielded fire stove design guide suggests adding $20 \mathrm{~cm}$ to the pot's diameter to set the overall stove diameter. This significantly increases the stove's mass and thermal capacity.

The additional thickness is designed to accommodate the pot skirt. The pot skirt is an important design feature as it improves conductive heat transfer by accelerating combustion gases through a small gap surrounding the pot. Adding $10 \mathrm{~cm}$ to the either side of the stove body allows for an 8 or $9 \mathrm{~cm}$ thick skirt (after cutting away a small amount of material for the combustion gas outlet). Given the measured mechanical strength of the clay and straw mixture, this is an excessive amount of material. Adding 10 $\mathrm{cm}$ to the overall diameter of the stove body $(5 \mathrm{~cm}$ on each side) should be adequate. This will allow for 3 to $4 \mathrm{~cm}$ thick pot skirt. The adjustments to the stove body thickness and pot skirt can be seen in Figure 5-2

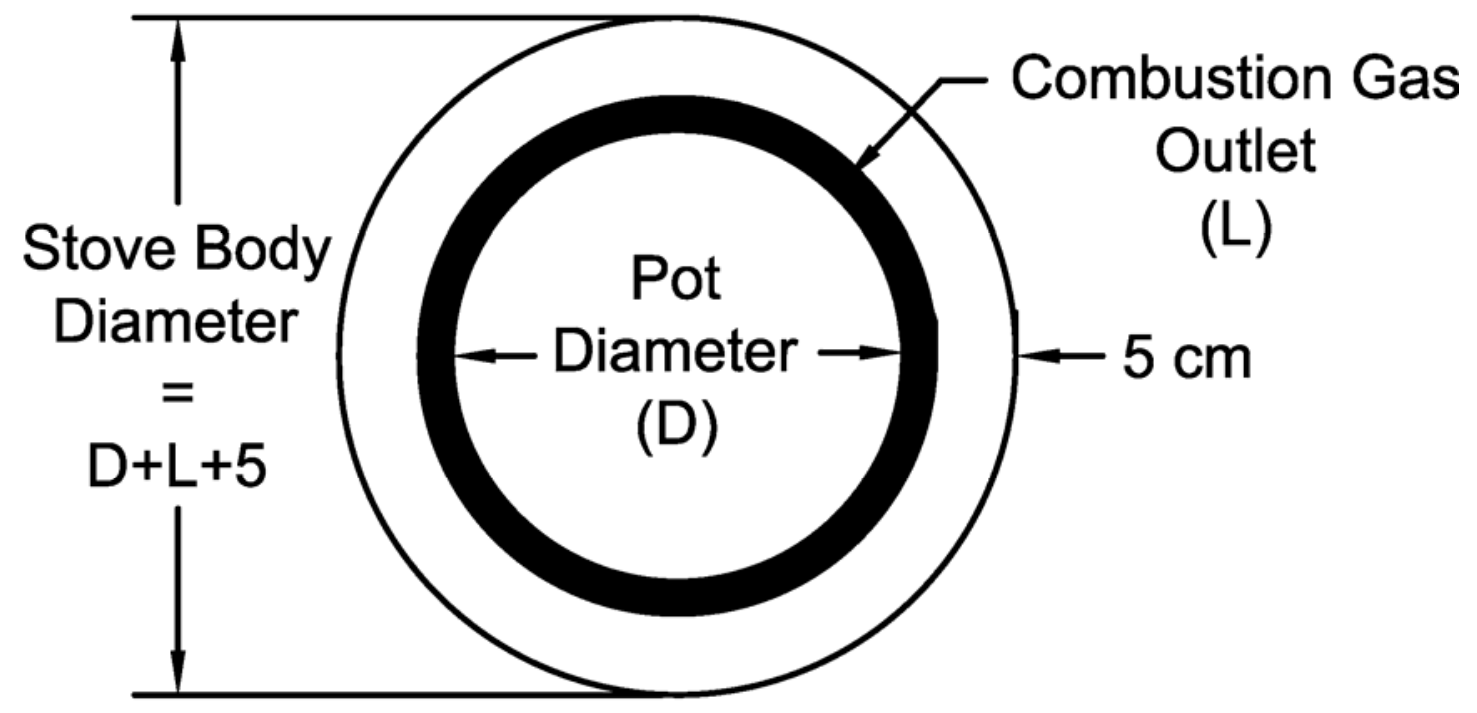

Figure 5-2 Pot skirt thickness and stove body diameter

Another option is to remove the clay pot skirt all together and use scrap metal to construct the skirt. The stove body will then only need to be wide enough to support the pot. The Recho Roket stove is an example of a mud stove similar in design to the GTZ-Uganda shielded fire stove but it instead utilizes a pot skirt constructed from scrap metal (used cans, sheet metal, etc). 


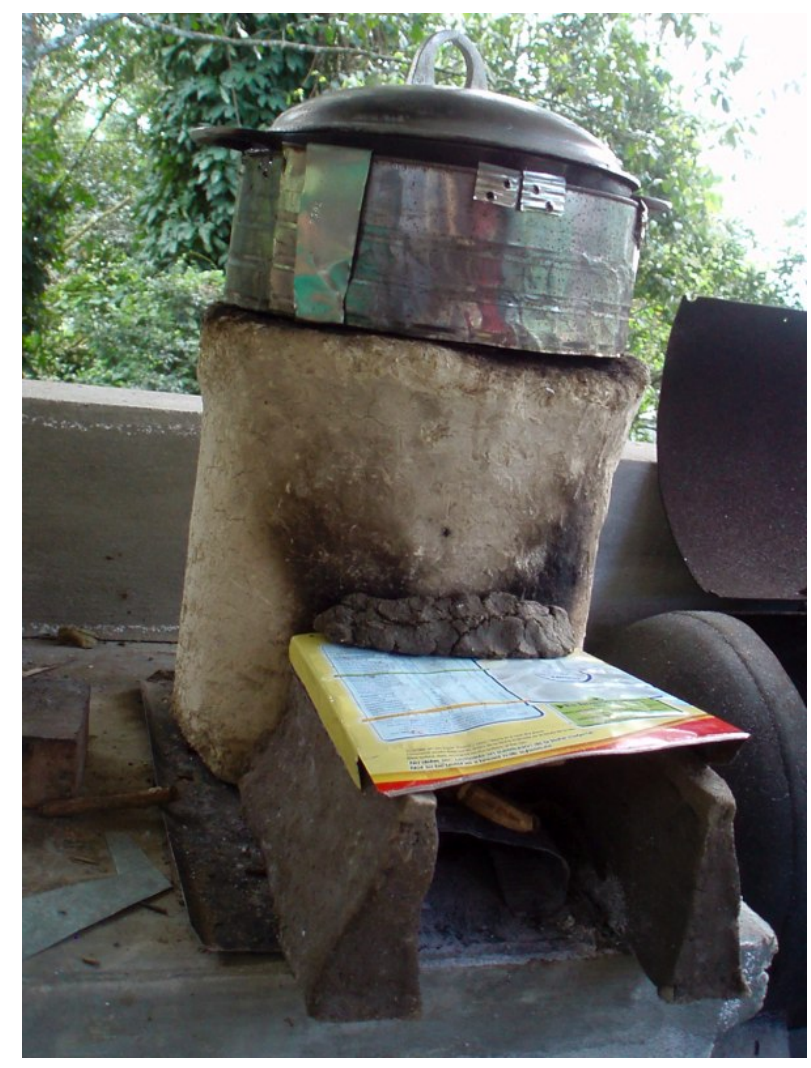

Figure 5-3 Recho Roket Stove (source: http://www.rechoroket.com/)

Table 5-2 Summary comparison of cook stove design improvements

\begin{tabular}{|l|l|}
\hline Engineering-based stove design improvements & User-based stove design improvements \\
\hline In creased stove height & Decreased stove height \\
Smaller fuel inlet diameter & Increased fuel inlet diameter \\
Smaller sized fuel & Larger sized fuel
\end{tabular}


The use of large, heavy stoves constructed with earthen materials is not an ideal intervention method when addressing energy use and indoor quality associated with biomass combustion. In some, if not many cases, these stoves will have poorer thermal performance and increased emissions concentrations when compared to to traditional open fires. If appropriate and sustainable in the context of the project site, smaller, more advanced stoves constructed using metal and fired ceramics are more likely to provide the desired improvements in fuel economy and air quality.

Despite their disadvantages, the strong stigma against earthen and mud stove may be unjustified. Earthen materials are of low cost and simple to work with. In areas where there is little incentive, economic or otherwise, to purchase an improved stove, motivating individuals to construct their own using available soil and organic material may be easier. The material analysis showed that when an adequate amount of organic material is mixed with the soil, the mixture will have thermal properties comparable to more advanced ceramics. If overall stove volume is kept to a minimum, avoiding excessive heat absorption in the stove body, these stoves will likely provide increased performance over traditional open fire cooking.

User involvement and input is vital to the success and sustainability of an improved stove implementation project. The suggested design improvement will not provide an idealized stove with respect to efficiency and emissions characteristics. Optimizing stove design based solely on a technical analysis of thermal performance and material properties will not guarantee adoption and use.

Compromises should be made between engineering knowledge and user input and feedback.

In addition to their involvement in the design and construction process, stove users should also receive training on additional methods of improving fuel economy and indoor air quality. This should include suggestions for increasing ventilation in the cooking space, proper fire tending techniques, and fuel selection. Collaborative discussions on the connection between poor indoor air quality and its adverse health effects will also likely lead to increased user involvement and innovation. 
Additional stoves using variations in the suggested design improvements should be built and tested. The mathematical heat loss model presented in this report can be used to predict stove body heat loss and temperature distribution for various design variations, but this should only be a preliminary test. Because of the high amount of variability associated with the biomass combustion process, there is no substitution for full scale performance testing.

Additional testing should also be conducted in the field. The Water Boiling Test and other laboratory based performance evaluations are not adequate representations of stove operation and cooking practices in real world settings. The qualitative survey portion of the Kitchen Performance Test (KPT) was used in this study to solicit user feedback. The full test also includes a quantitative measure of household fuel use over a prescribed period of time both before and after stove implementation. The Kitchen Performance Test provides a real world assessment of a stove's efficiency while gaining valuable user feedback.

The Partnership of Clean Indoor Air has also produced a Controlled Cooking Test (CCT) which may be valuable when evaluating the performance of earthen stoves. The Controlled Cooking Test involves preparing a standard meal common to the communities targeted in the stove implementation project. Conducted in a controlled setting, the CCT allows for simultaneous emissions testing.

Further analysis should also be conducted with variations in material mixtures. The clay content of these earthen mixtures is likely to have the greatest affect on the material's thermal properties. Increasing the ratio of organic matter to clay content may improve thermal performance, but this may also decrease the mechanical strength and durability of the mixture.

Different types of binders both organic and inorganic should be evaluated. Straw was tested in this study because it was readily available in both Mauritania and Mali. Crop residue and other types of plant matter may also make suitable binders for a mud mixture. Inorganic material like pumice stone is lightweight and porous. If available in the project site, it is likely to improve a mixture's thermal properties. The use of refuse like paper and plastic may also result in a suitable mud mixture in addition to removing material from the waste stream. 
(2002). The World Health Report 2002: Reducing Risks, Promoting Health Life. Geneva, Switzerland, World Health Organization.

(2004). How to Build the Improved Household Stoves, Republic of Uganda-Ministry of Energy and Mineral Development, German Technical Cooperation.

Ahuja, D. R., V. Joshi, et al. (1987). "Thermal performance and emission characteristics of unvented biomass-burning cookstoves: A proposed standard method for evaluation." Biomass 12(4): 247-270.

Andreatta, D. (2003) Heat loss from stoves: Thermal properties of insulative bricks.

Baldwin, S. F. (1987). Biomass stoves : engineering design, development, and dissemination. Arlington, Va., USA

Princeton, N.J., USA, Volunteers in Technical Assistance ;

Center for Energy and Environmental Studies, Princeton University.

Balis, B., D. Ogle, et al., Eds. (2007). The Water Boiling Test (WBT), Household Energy and Health Programme, Shell Foundation.

Balis, B., D. Ogle, et al. (2007). The Water Boiling Test (WBT) V3.0, Household Energy and Health Programme, Shell Foundation.

Balis, R., K. Smith, et al. (2007). Kitchen Performance Test (KPT) V3.0, Household Energy and Health Programme, Shell Foundation.

Barnes, D. F. (1994). What makes people cook with improved biomass stoves? : a comparative international review of stove programs. Washington, D.C., World Bank.

Binici, H., O. Aksogan, et al. (2007). "Thermal isolation and mechanical properties of fibre reinforced mud bricks as wall materials." Construction and Building Materials 21(4): 901-906.

Bruce, N., R. Perez-Padilla, et al. (2002). The health effects of indoor air pollution exposure in developing countries. Geneva, Switzerland, World Health Organization.

Bryden, M., D. Still, et al. (2005). Design Principles for Wood Burning Cook Stoves, Aprovecho Research Center, Partnership for Clean Indoor Air, Shell Foundation.

Bussmann, P. (1988). Woodstoves: Theory and Applications in Developing Countries. Faculty of Applied Physics, Eindhoven University of Technology. Ph.D.: 182. 
Hudelson, N., K. M. Bryden, et al. (2002). Global Modeling and Testing of Rocket Stove Operating Variations. Ames, IA, lowa State University, Aprovecho Research Center.

Incropera, F. P. (2007). Introduction to heat transfer. Hobokenm NJ, Wiley.

Mihelcic, J. R., J. B. Zimmerman, et al. (2010). Environmental engineering : fundamentals, sustainability, design. Hoboken, NJ, Wiley.

Ndiema, C. K. W., F. M. Mpendazoe, et al. (1998). "Emission of pollutants from a biomass stove." Energy Conversion and Management 39(13): 1357-1367.

Seppänen, O. A., W. J. Fisk, et al. (1999). "Association of Ventilation Rates and CO2 Concentrations with Health andOther Responses in Commercial and Institutional Buildings." Indoor Air 9(4): 226-252.

Still, D., M. Pinnell, et al. (2003). "Insulative ceramics for improved cooking stoves." Boiling Point: A practioner's journal on household energy, stoves and poverty education(49).

Warwick, H. and A. Doig (2004). Smoke - the killer in the kitchen. London, UK, ITDG Publishing. 


\section{APPENDICES}

\section{A. FINITE DIFFERENCE MODEL MATLAB CODE}

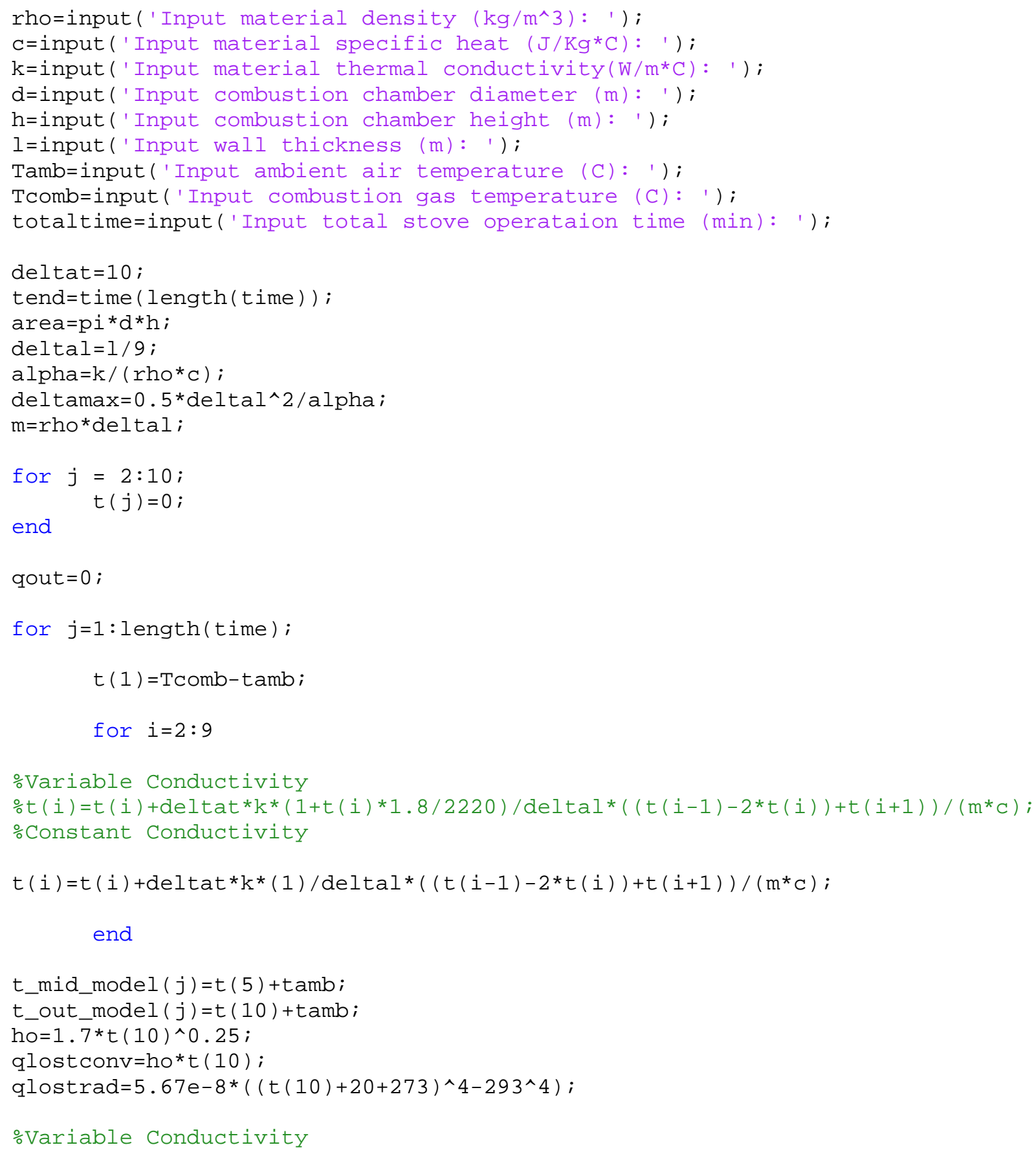


4/28/11 12:19 PM H: \MATLAB\Stove_Heat_Loss_Model.m 2 of 2

$\% \mathrm{t}(10)=\mathrm{t}(10)+\operatorname{deltat} /\left(\mathrm{m}^{*} \mathrm{c} / 2\right) *(\mathrm{k} *(\overline{1}+\mathrm{t}(9) * 1.8 / 2220) / \operatorname{deltal} *(\mathrm{t}(9)-\mathrm{t}(10))-$

qlostconvqlostrad);

\%Constant Conductivity

$\mathrm{t}(10)=\mathrm{t}(10)+\operatorname{deltat} /\left(\mathrm{m}^{*} \mathrm{c} / 2\right) *\left(\mathrm{k}^{*}(1) / \operatorname{deltal} *(\mathrm{t}(9)-\mathrm{t}(10))-\mathrm{qlostconv}-\mathrm{qlostrad}\right) ;$ qout=qout+area*deltat ${ }^{*}($ qlostconv+qlostrad $)$;

hoeff $=($ qlostconv+qlostrad $) / t(10)$;

end

qbody=area* ${ }^{*} c^{*}(\mathrm{t}(2)+\mathrm{t}(3)+\mathrm{t}(4)+\mathrm{t}(5)+\mathrm{t}(6)+\mathrm{t}(7)+\mathrm{t}(8)+\mathrm{t}(9)+\mathrm{t}(1) / 2+\mathrm{t}(10) / 2)$;

totalqlost $=($ qout + qbody $) / 10 \wedge 6$ 
B. DIGITAL FILES ON ATTACHED CD

\begin{tabular}{|l|l|}
\hline File Name & Description \\
\hline User_Surveys.pdf & Complete user surveys \\
\hline WBT_data-calculation_Stove_3.0.xIsx & $\begin{array}{l}\text { Performance calculations from the water boiling } \\
\text { test for the shielded fire rocket stove }\end{array}$ \\
\hline WBT_data-calculation_3 stone_3.0.xlsx & $\begin{array}{l}\text { Performance calculations from the water boiling } \\
\text { test for the three stone fire stove }\end{array}$ \\
\hline Stove Body Temperature.xlsx & $\begin{array}{l}\text { Temperature measurments at thermocouples } \\
\text { buried in the shielded fire rocket stove body }\end{array}$ \\
\hline Stove_Heat_Loss_Model.m & $\begin{array}{l}\text { Matlab prgram file of the finite difference model } \\
\text { for stove heat loss }\end{array}$ \\
\hline Stove_Heat_Loss_Model.pdf & Finite difference model code in pdf format \\
\hline CO_CO2_Shielded Fire Rocket Stove.xIsx & $\begin{array}{l}\text { Carbon monoxide and carbon dioxide emissions } \\
\text { for the shielded fire rocket stove }\end{array}$ \\
\hline PM2.5_Shielded Fire Rocket Stove.xlsx & $\begin{array}{l}\text { PM2.5 concentrations for the shielded fire rocket } \\
\text { stove }\end{array}$ \\
\hline CO_CO2_3Stone Fire.xlsx & $\begin{array}{l}\text { Carbon monoxide and carbon dioxide emissions } \\
\text { for the three stone fire }\end{array}$ \\
\hline PM2.5_3Stone Fire.xIsx & PM2.5 concentrations for the three stone fire \\
\hline Specific_Heat_Calorimeter.xlsx & Calorimeter data for specific heat calculation \\
\hline Thermal conductivity.xlsx & $\begin{array}{l}\text { Temperature data for thermal conductivity } \\
\text { measurement }\end{array}$ \\
\hline Compression Strength.xlsx & Data of compression strength tests \\
\hline
\end{tabular}


C. HUMAN SUBJECTS RESEARCH APPROVAL: MICHIGAN TECHNOLOGICAL UNIVERSITY 


\section{Office of Research Integrity and Compliance}

302 Lakeshore Center

1400 Townsend Drive

Houghton, Ml 49931

906.487 .2902

\section{MEMO}

TO: Dr. Kurt Paterson, Civil \& Environmental Engineering

CC: Nicholas Schreiner, Civil \& Environmental Engineering

FROM: Joanne Polzien, Director Research Integrity and Compliance

DATE: June 14, 2010

\section{SUBJECT: Approval M0614}

Your application to use human subjects in research or classroom situations has been reviewed with the following determination:

Protocol \#: M0614

Protocol Title: "Evaluating Rocket - Lorena Stove Performance in Mali, West Africa"

Approved Dates: June 14, 2010 through June 13, 2011

Approvals are granted for up to a one year period. You will need to request a continuation for each year of the project six weeks prior to the end date indicated above for each year of the project. The Office of Research Integrity and Compliance will make every effort to send the Principal Investigator annual reminders. However, the Principal Investigator is responsible for submitting annual Continuation Forms in advance of the expiration date for the project. It is very important that these expiration dates are not missed. Failure to submit annual review materials on time will result in the termination of this protocol.

This approval applies only for this project, and only under the conditions and procedures described in the application; if any changes are made in the protocol or conditions set forth in the application, the principal investigator must obtain a separate approval before these changes take place. The approved project will be subject to surveillance procedures requiring periodic review. This review will consist of consulting with the principal investigator and examining the appropriate project records.

Individual identification of human subjects in any publication is an invasion of privacy. Before beginning a project involving human subjects, and only if required, the principal investigator must obtain a properly executed informed consent from each subject and/or the person legally responsible for the subject. If a consent form has been reviewed and approved it has been attached with an official date stamp on it. Only copies of the official date stamped informed consent is to be distributed to participants relating to this project. If any changes or modifications are needed regarding this form, you must first submit the revised document for review and approval prior to use. The principal investigator must retain informed consent forms on file for at least three years after the end of the project. If a project involves a high level of risk, copies of the signed informed consent forms must be filed with the Human Subjects Committee; if this is the case, you will be notified.

This document is on file in the Office of Research Integrity and Compliance. If you have any questions, please contact me at 487-2902 or jpolzien@mtu.edu. 